\title{
Buoyancy sources for a large, unrooted mountain range, the Sierra Nevada, California: Evidence from xenolith thermobarometry
}

\author{
Mihai N. Ducea and Jason B. Saleeby \\ Division of Geological and Planetary Sciences, California Institute of Technology, Pasadena
}

\begin{abstract}
Xenoliths hosted by Cenozoic volcanic flows and plugs from the Central Sierra Nevada and Eastern Sierra Nevada, Owens Valley, and Inyo Mountains were studied for petrography and thermobarometry. The Central Sierra Nevada suite consists of abundant lower crustal feldspathic granulites, garnet clinopyroxenites, and mantle-derived peridotites and garnet websterites. Mafic crustal assemblages occur down to $\sim 65-70 \mathrm{~km}$, although below $35-40 \mathrm{~km}$, they are mainly in the eclogite facies. In contrast, the Eastern Sierra Region suites show peridotitic, pyroxenitic, and harzburgitic assemblages at depths of $\geq 35-40 \mathrm{~km}$. They define an adiabat in PT space $\left(\mathrm{T} \sim 1180-1250^{\circ} \mathrm{C}\right)$, suggesting the presence of the asthenospheric upper mantle close to the base of the crust. The ultramafic mantle rocks from the Central Sierra Nevada also define an adiabatic slope in PT space, possibly an artifact of side heating from the east. There is xenolith evidence that the Sierra Nevada lost about half of its original crust on the eastern side of the range. Regardless of the actual mechanism of crustal thinning, the loss of the eclogitic lowermost crust and replacement by peridotite in the eastern Sierra Nevada is a process accompanied by a substantial density decrease $\left(>100 \mathrm{~kg} / \mathrm{m}^{3}\right)$. Overall, if the mechanism of eclogitic lowermost crust removal is viable, there are enough buoyancy sources to explain topographic differences between the Sierra Nevada and the adjacent Basin and Range, assuming isostatic equilibrium.
\end{abstract}

\section{Introduction}

The Southern Sierra Nevada, California, is a high standing mountain range (2800-m mean elevation) relative to the adjacent Basin and Range Province (1000-m mean elevation) to the east and the Great Valley (sea level elevation) to the west. The Sierra Nevada is composed primarily of a large, Cordilleran-type batholith [Saleeby, 1990], a Mesozoic magmatic arc similar to the modern Andes. The Sierra Nevada was traditionally believed to have a thick, $\sim 55 \mathrm{~km}$ root [Bateman and Eaton, 1967] which compensates the mountain range's elevation. Recent teleseismic results [Jones et al., 1994] and active and passive seismic experiments [Wernicke et al., 1996; Park et $a l ., 1995]$, in contrast, show that the Southern Sierra Nevada is underlain by a relatively thin, $\sim 35 \mathrm{~km}$ thick crust. In light of these results, a different mechanism of compensation of the Sierra Nevada must be found. The upper mantle has to be buoyant enough to explain much of a $\sim 150 \mathrm{mGal}$ negative Bouguer anomaly [Oliver, 1977] that characterizes the Sierra Nevada. The Sierra Nevada mountain range is located at the edge of a rift province (the Basin and Range). The topography support mechanisms may be related to heating of this rift "shoulder" and upwelling of hot asthenosphere [Crough and Thompson, 1977].

The only direct samples of the lower crust and the uppermost mantle in the region are represented by xenoliths hosted by numerous young volcanic flows and plugs. In this paper, we are exploring the source(s) of upper mantle/lower crustal buoy-

Copyright 1996 by the American Geophysical Union.

Paper number $95 \mathrm{JB} 03452$.

0148-0227/96/95JB-03452\$05.00 ancy in the area, based on xenolith evidence as a proxy for the Sierra Nevada lithospheric structure. The crustal and upper mantle compositions derived from xenolith studies are very different in the central part and the eastern side of the mountain range. These differences permit us to assess the possible mechanisms of support for the Sierra Nevada. Two potential mechanisms for lowering the density in the uppermost seismologically defined mantle are discussed in detail: (1) the replacement of lithosphere with asthenosphere, and (2) eclogite removal during crustal thinning.

\section{Xenolith Petrography}

Lower crustal and upper mantle xenoliths from young basaltic volcanic rocks in the Sierra Nevada and Owens Valley were previously described by Domenick et al. [1983], Dodge et al. [1986, 1988], Mukhopadhyay [1989, 1991b], Mukhopadhyay and Manton [1994], Ducea and Saleeby [1994], Wilshire et al. [1988], and Beard and Glazner [1995]. In this paper we use all previous reports on thermobarometry of the Sierra Nevada xenoliths, in addition to our results. The xenolith-bearing localities used in this study are shown in Figure 1, and the compositions and ages of the host volcanics are given in Table 1. The xenolith-bearing volcanics can be divided in two broad groups based on location and age. One suite located in the central Sierra Nevada consists mainly of Miocene volcanics (which will be named "Central Sierra Nevada" throughout the paper), and the other consists of Quaternary volcanics of the eastern Sierra Nevada, Owens Valley, and Inyo Mountains (the "Eastern Sierra Region suite"). Figure 2 is a histogram of petrographic compositions of xenoliths sampled from both the Central Sierra Nevada and the Eastern Sierra Region, and 

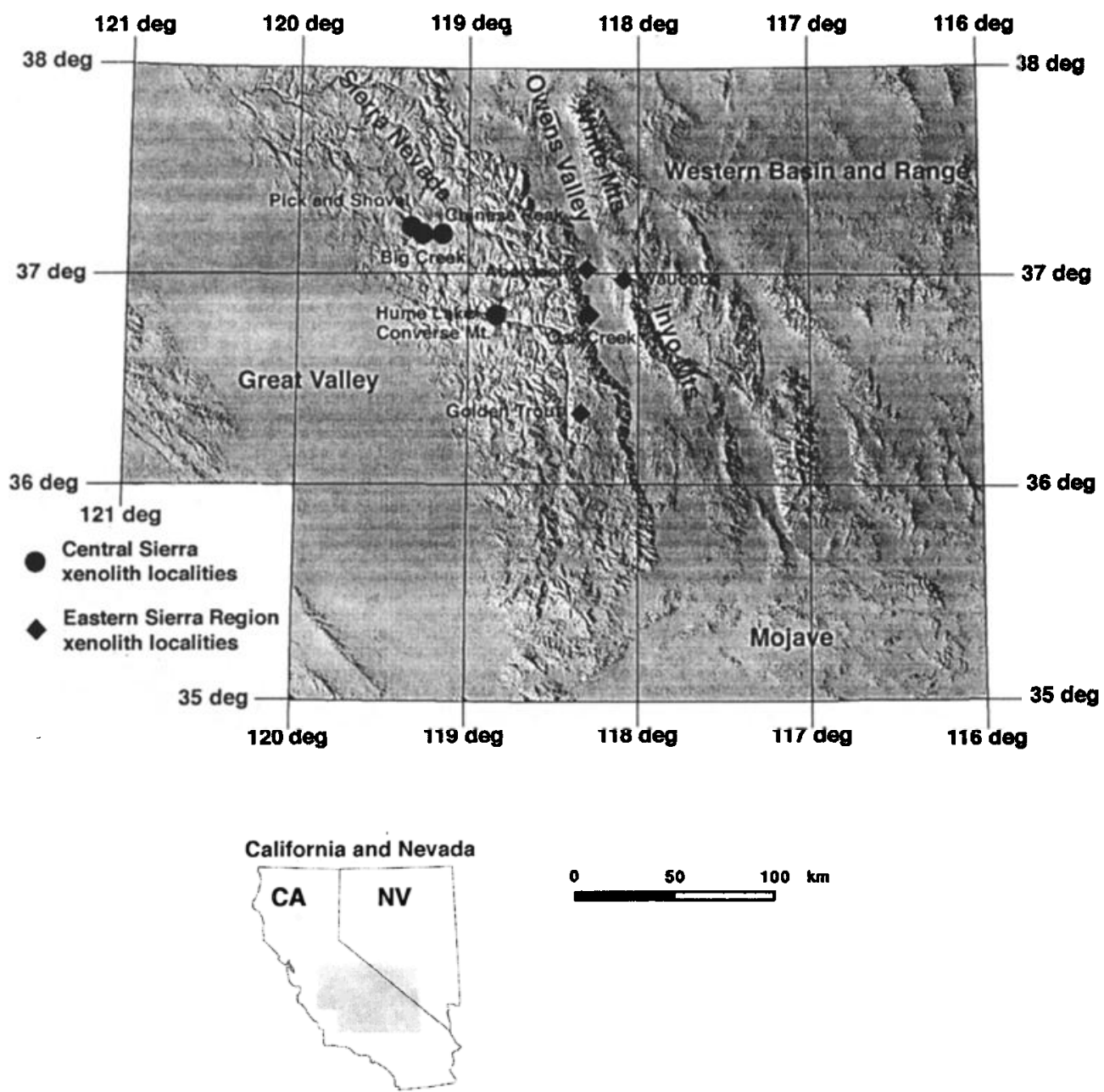

Figure 1. Map showing the distribution of xenolith-bearing flows from the Sierra Nevada, Owens Valley, and Inyo Mountains investigated in this study.

includes data from Mukhopadhyay [1989], our collection, and F. Dodge's collection, which is stored at the Smithsonian Institution.

There are significant compositional and equilibration temperature differences between the xenoliths of the two groups. An average age difference of $\sim 8 \mathrm{Ma}$ between the Central Sierra Nevada and the Eastern Sierra Region xenolith-bearing volcanics is a serious limitation in our attempt to infer in a static manner any lateral variations in the Sierran lithosphere from the xenolith petrology, especially because the eastern
Sierra was probably subject to significant extension in the past $10 \mathrm{~m} . y$. This age difference, however, sheds light on the recent dynamical evolution of the Sierra Nevada.

Below, we will describe the petrography of the two distinct suites.

\section{Central Sierra Nevada Suite}

The Central Sierra Nevada suite is rich in both crustal and mantle xenoliths (Figure 2). Most of the crustal xenoliths are

Table 1. Location, Composition and Age of the Xenolith-Bearing Volcanics Studied

\begin{tabular}{|c|c|c|c|c|c|c|}
\hline Xenolith Locality & Group & Location & $\begin{array}{l}\text { Host Rock } \\
\text { Composition }\end{array}$ & Age, Ma & $\begin{array}{l}\text { Method of } \\
\text { Dating }\end{array}$ & Reference \\
\hline Big Creek & CS & $37^{\circ} 13^{\prime} \mathrm{N}, 119^{\circ} 16^{\prime} \mathrm{W}$ & trachyandesite & 8.3 & $\mathrm{Rb}-\mathrm{Sr}$ & Dodge et al. [1988] \\
\hline Pick and Shovel & CS & $37^{\circ} 15^{\prime} \mathrm{N}, 119^{\circ} 20^{\prime} \mathrm{W}$ & trachyandesite & $\begin{array}{c}\text { not dated, cogenetic } \\
\text { with Big Creek, } \\
\text { probably } \sim 10 \mathrm{Ma}\end{array}$ & & \\
\hline $\begin{array}{l}\text { Hume Lake/Converse } \\
\text { Mountain }\end{array}$ & CS & $36^{\circ} 50^{\prime} \mathrm{N}, 118^{\circ} 50^{\prime} \mathrm{W}$ & alkali basalt & $\begin{array}{l}\text { not dated, probably } \\
\text { Miocene }\end{array}$ & & \\
\hline Golden Trout & ES & $36^{\circ} 22^{\prime} \mathrm{N}, 118^{\circ} 20^{\prime} \mathrm{W}$ & alkali basalt & $\sim 0.005$ & & Moore and Sisson [1985] \\
\hline Aberdeen & ES & $37^{\circ} 03^{\prime} \mathrm{N}, 118^{\circ} 18^{\prime} \mathrm{W}$ & alkali basalt & 0.09 & $\mathbf{K}-\mathbf{A r}$ & Luedke and Smith [1981] \\
\hline Oak Creek & ES & $36^{\circ} 50^{\prime} \mathrm{N}, 118^{\circ} 17^{\prime} \mathrm{W}$ & alkali basalt & 0.15 & $\mathrm{~K}-\mathrm{Ar}$ & Luedke and Smith [1981] \\
\hline Waucoba & ES & $37^{\circ} 00^{\prime} \mathrm{N}, 118^{\circ} 05^{\prime} \mathrm{W}$ & alkali basalt & 0.8 & $\mathrm{~K}-\mathrm{Ar}$ & Ormerod et al. [1988] \\
\hline
\end{tabular}

CS, Central Sierra Nevada suite; ES, Eastern Sierra Region suite. 
mafic in composition. Other compositions, such as metasediments, diorites, and amphibolites, are sparse and have not been investigated in detail in this study.

The mafic xenoliths are gabbros, cumulate gabbros, feldspathic granulites, garnet clinopyroxenites, and websterites. Many of the mafic xenoliths have igneous textures. The gabbros consist of plagioclase, clinopyroxene, orthopyroxene, hornblende, and biotite. Accessory phases include magnetite, ilmenite, quartz, sphene, apatite, zircon, and orthoclase. Commonly, the gabbros have cumulate textures; these rocks are centimeter-scale layered rocks. The size of the xenolith is comparable to the scale of layering, which makes textural identification difficult. Clinopyroxene and orthopyroxene form the mafic layers and are commonly rimmed by hornblende. A few samples also have garnet as a cumulus phase. Small, grossularrich garnet crystals crystallized within the plagioclase intercumulus layers. The presence of garnet is an indication of the deep provenance of most of the xenolithic gabbros, although textural and mineralogical evidence show that the gabbros are not very different lithologically from some of the western Sierra Nevada mafic plutons [Saleeby and Sharp, 1982; ClemensKnott, 1992], which formed at depths shallower than $15 \mathrm{~km}$.
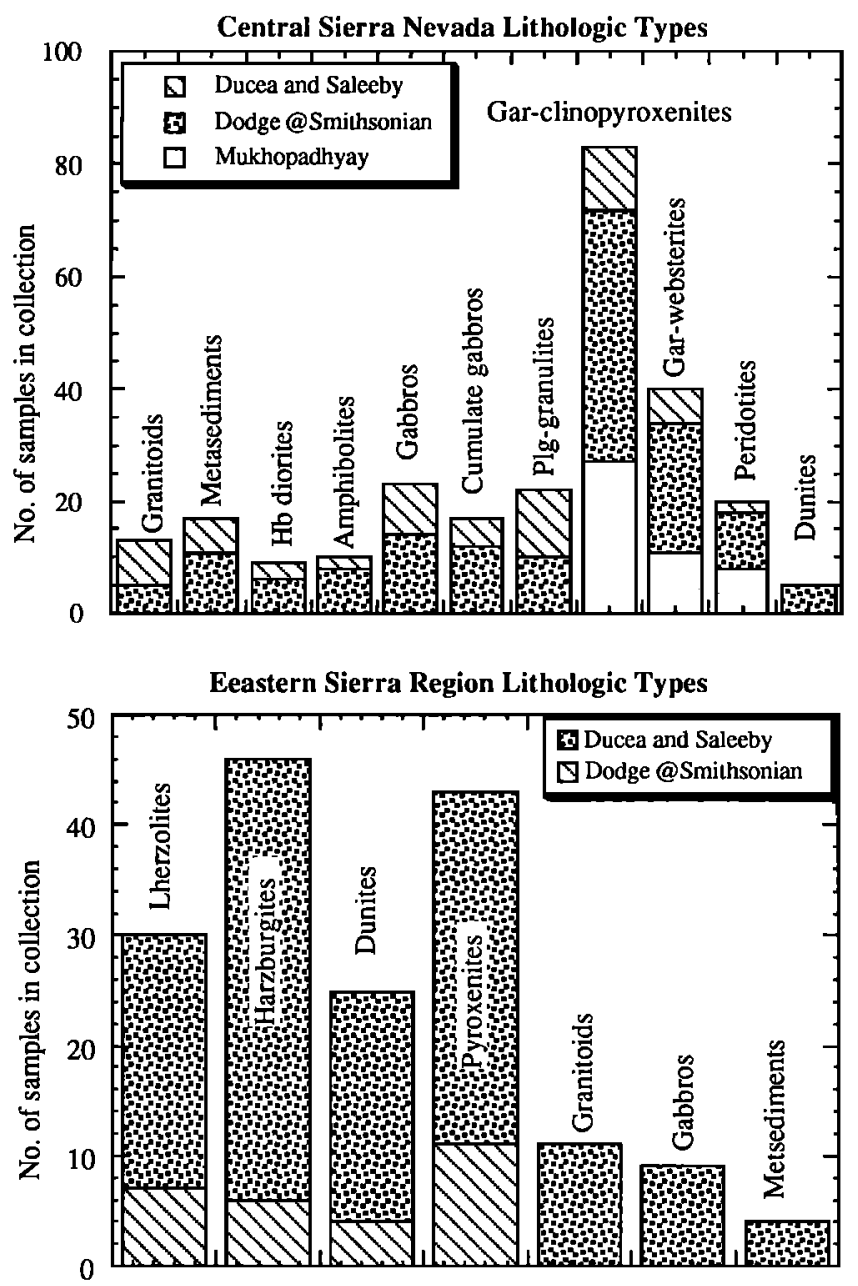

Figure 2. Lithologic types and abundance of sampled xenoliths from the (a) Central Sierra Nevada and (b) Eastern Sierra Region present in the Ducea and Saleeby collection, the Dodge collection stored at the Smithsonian Institution, as well as the samples studied by Mukhopadhyay [1989].
Table 2. Average Major Element Composition of Various Mafic Xenoliths of the Central Sierra Nevada Suite

\begin{tabular}{lcccc}
\hline $\begin{array}{l}\text { Oxide, } \\
\text { wt \% }\end{array}$ & Gabbro & $\begin{array}{c}\text { Cumulate } \\
\text { Gabbro }\end{array}$ & $\begin{array}{c}\text { Feldspathic } \\
\text { Granulite }\end{array}$ & $\begin{array}{c}\text { Garnet } \\
\text { Clinopyroxenite }\end{array}$ \\
\hline $\mathrm{SiO}_{2}$ & 49.7 & 51.5 & 50.3 & 50.1 \\
$\mathrm{Al}_{2} \mathrm{O}_{3}$ & 11.8 & 19.5 & 10.3 & 12.1 \\
$\mathrm{FeO}_{\text {tot }}$ & 8.9 & 5.1 & 7.2 & 6.9 \\
$\mathrm{MgO}$ & 12.7 & 7.6 & 13.1 & 14.2 \\
$\mathrm{CaO}$ & 13.3 & 11.4 & 14.3 & 15.4 \\
$\mathrm{Na}_{2} \mathrm{O}$ & 3.2 & 1.6 & 2.3 & 1.2 \\
$\mathrm{~K}_{2} \mathrm{O}$ & 0.3 & $\cdots$ & 0.4 & $\cdots$ \\
\hline
\end{tabular}

Granulite xenoliths vary from $20 \%$ to $80 \%$ plagioclase with mafic phases dominated by two pyroxenes and garnet. Accessory quartz is common. Textures are granoblastic, and some xenoliths display a distinct, subparallel alignment of tabular laths of plagioclase. Banding is suggestive of metamorphic gneissic texture but could well be inherited igneous lamination [Dodge et al., 1986]. The phase mineralogy and bulk composition reconstructed from point counting suggest that the gabbros, cumulate gabbros, and mafic feldspathic granulites share a common origin and are most likely deep batholithic rocks. Preliminary trace element studies on these rocks [Ducea et al., 1995] are consistent with a cumulate origin of the mafic feldspathic rocks of the Central Sierra Nevada suite.

A distinct petrographic group is represented by the garnet clinopyroxenites. They have been identified at the Big Creek, Chinese Peak, Pick and Shovel, and Hume Lake locations. The garnet clinopyroxenites represent a ubiquitous assemblage in the Central Sierra xenoliths. They have also been called "granulites" or "eclogites" by Dodge et al. [1986] and Dodge and Bateman [1988]. They have equigranular, bimineralic, clinopyroxene-garnet assemblages varying in composition from garnetites to clinopyroxenites. Coarse, subidioblastic to rounded garnets are enclosed in a xenomorphic matrix of clinopyroxenes. Minor amounts of rutile, spinel, and secondary amphibole are present. Commonly, the garnet is replaced by fine-grained secondary assemblages consisting of rutile, two-phase Fe-Ti oxides, secondary amphibole, and rare biotite, which is replaced by opaque pseudomorphs [see also Mukhopadhyay, 1989]. Dodge et al. [1986] described sporadic layered xenoliths which consist of bands of garnet clinopyroxenite which show granoblastic mosaic textures interlayered with feldspathic-rich zones containing subordinate amounts of garnet, identical in composition with the granulites described above. Given the geological framework of the Sierra Nevada, garnet clinopyroxenite xenoliths can be cognate inclusions, subordinate mafic material (e.g., veins) within an ultramafic upper mantle, batholithrelated cumulates, former mafic liquids frozen in the lower crust, partial melting residues, older continental crust, or subducted oceanic crust. The above textural evidence, as well as preliminary rare earth element (REE) investigations [Ducea et al., 1995], suggest a cumulate origin for most of the mafic lower crustal xenoliths of the Central Sierra, including the garnet clinopyroxenites. The focus of this paper is on the thermobarometry of the different xenolith assemblages; testing petrogenetic hypotheses for the garnet clinopyroxenites and their link with the other mafic assemblages is currently under investigation. However, we point out here the similarity in the average major element chemistry of the gabbros, cumulate gabbros, granulites, and garnet clinopyroxenites (Table 2). 
Another distinct group of xenoliths of the Central Sierra Nevada is represented by garnet websterites. The garnet grains are commonly clouded with inclusions, whereas clinopyroxene has local orthopyroxene exsolution lamellae. The texture is granoblastic characterized by polygonization of large, centimeter-size grains into smaller millimeter-size grains with abundant triple points and equigranular mosaic aspect. Accessory minerals include $\mathrm{Cu}-\mathrm{Fe}$ sulfides (mainly chalcopyrite), rutile, and amphibole.

Garnet peridotites, spinel-garnet peridotites, and spinel peridotites [Dodge et al., 1988; Mukhopadhyay and Manton, 1994] were previously described in the Central Sierra suite. We sampled a few garnet peridotites and spinel peridotites with granoblastic polygonal to allotriomorphic granular textures. Typically, the ultramafic xenoliths were recovered as samples smaller than $5 \mathrm{~cm}$ in diameter.

\section{Eastern Sierra Nevada Region Suite}

The Eastern Sierra Region suite is very rich in upper mantle assemblages (Figure 2) and is very different from the Central Sierra suite. No garnet has been recorded in any of the Eastern Sierra Region xenoliths, nor have mafic granulites been identified.

Xenoliths of granodioritic compositions from Golden Trout, Oak Creek, and Aberdeen resemble batholithic rocks of the Eastern Sierra Nevada in composition and texture. Some of them, however, have a distinct gneissic texture, commonly displaying a mylonitic texture with the mafic minerals (hornblende and biotite) stretched in foliation planes.

Gabbroic xenoliths are layered cumulates having green, 2- to $5-\mathrm{cm}$ bands of augite alternating with plagioclase layers. Sparse hornblende diorites grading to hornblendites with pegmatitic textures are present as well. The typical size of these xenoliths is $2-40 \mathrm{~cm}$ in diameter.

Clinopyroxenites, orthopyroxenites, and spinel websterites are very common in the Eastern Sierra Region suite (Figure 2). They contain rare olivine and small amounts of anorthitic plagioclase. The textures are metamorphic and are usually porphyroblastic. Accessory phases include Fe-Ti oxides and sulfides.

Spinel lherzolites are common. There are two textural types, an allotriomorphic type, with grain size up to $0.5 \mathrm{~cm}$, and a porphyroclastic type, sometimes completely annealed, with grain size typically of the order of a few millimeters. Larger, clastic olivine and orthopyroxene grains are occasionally present as relics within the finer-grained porphyroclastic peridotites.

Harzburgites and spinel dunites with minor amounts of orthopyroxene are texturally very similar to the porphyroclastic lherzolites. The ultramafic lithologies described above are endmember rocks, and transitions between them are common. Most of the ultramafic xenoliths are small samples, $1-4 \mathrm{~cm}$ in diameter.

\section{Mineral Chemistry}

\section{Analytical Methods}

The mineral chemistry of each petrographic type was investigated. Polished rock thin sections were analyzed on a JEOL 733 electron microprobe fitted with five wavelength spectrometers. The accelerating voltage was $15 \mathrm{keV}$, the probe current was $25 \mathrm{nA}$ (measured on brass), count time was $60-80 \mathrm{~s}$, and probe diameter was $10 \mu \mathrm{m}$. Sodium was analyzed first in order to reduce alkali migration. At least five grains of each mineral phase were analyzed in every thin section to check for equilibrium attainment. Cores, rims, and spots on the extreme outer limit of grains ("extreme rims") were measured for each analyzed grain, usually averaged from two to five analyses. Several traverses were performed across the most important phases. Only the granulites showed noticeable compositional gradients, whereas mosst of the garnet clinopyroxenites as well as the high-temperature rocks showed uniform compositions. The extreme rim compositions were not used in interpretations because they systematically showed effects of heating due to entrapment in the host melt. We used the chemistry of the phases in conjunction with point countings on thin sections to calculate the major element chemistry of some of the xenoliths (reported in Table 2).

Described below are the compositions of the mineral phases involved in the thermobarometric calculations. Representative analyses given in Table 3 are average values for mineral rims consisting of two to five spots.

\section{Central Sierra Nevada Suite}

Granulites and gabbros. Clinopyroxenes are diopsidic. In thin section, they show weak pleochroism and are often twinned. The magnesium number $(\mathrm{Mg} / \mathrm{Mg}+\mathrm{Fe})$ varies between 0.42 and 0.7 . The ${ }^{\mathrm{NV}} \mathrm{Al} /{ }^{\mathrm{Vl}} \mathrm{Al}$ ratios vary from $1 / 2$ to 2 but are commonly close to 1 . The $\mathrm{Fe}^{3+}$ calculated using the method of Papike et al. [1974] is less than $10 \%$ of the total Fe. The $\mathrm{Na}_{2} \mathrm{O}$ varies between $0.39 \%$ and $1.75 \%$; none of the pyroxenes have a significant jadeitic component.

Orthopyroxenes consist of bronzite and hypersthene compositions. In thin section, they show weak green-pink pleochroism. $\mathrm{Al}_{2} \mathrm{O}_{3}$ content is normally less than $3 \%$. However, some orthopyroxenes have up to $15-16 \% \mathrm{Al}_{2} \mathrm{O}_{3}$. This feature was observed in both orthopyroxene extreme rims and sometimes in single grains and is probably a pyrometamorphic product due to xenolith heating in the host magma [Zhang et al., 1993]. These Al-orthopyroxenes are not pure phases and were not used for thermobarometry.

Garnet compositions are shown in Figure 3. The garnet clinopyroxenites (see below) are richer in the grossular component than the feldspathic granulites garnets, but they all fall in the group B compositional range of Coleman et al. [1965]. The garnet in rocks with igneous textures (gabbros) is very rich in the grossular component (Figure 3) and grew at the expense of An-rich plagioclase, perhaps upon cooling, and at high pressure. The garnets are commonly surrounded by thick kelyphitic rims [see Mukhopadhyay, 1991b].

Plagioclase compositions vary from $95.5 \%$ to $38 \%$ anorthite (An). The An content obtained from electron probe data has also been determined with optical methods; the values agree to within $5 \%$.

Garnet clinopyroxenites. Clinopyroxenes in the garnet clinopyroxenites are very similar in composition to those in the feldspathic granulites (in excellent agreement with data from Mukhopadhyay [1989]). They are almost always unzoned. Amphiboles formed locally along rims. Their chemistry is dominated by quadrilateral components (i.e., have a low jadeitic component). The chemistry of the clinopyroxenes from granulites and garnet clinopyroxenites form continuous trends for all major oxides and elements. In the quadrilateral diagram, clinopyroxenes from the granulites and garnet clinopyroxenites display a continuous linear trend, suggesting a common origin (Figure 4). In Figure 4 we plot the Ca content versus the Mg\# 
Table 3. Representative Mineral Compositions of the Analyzed Xenoliths

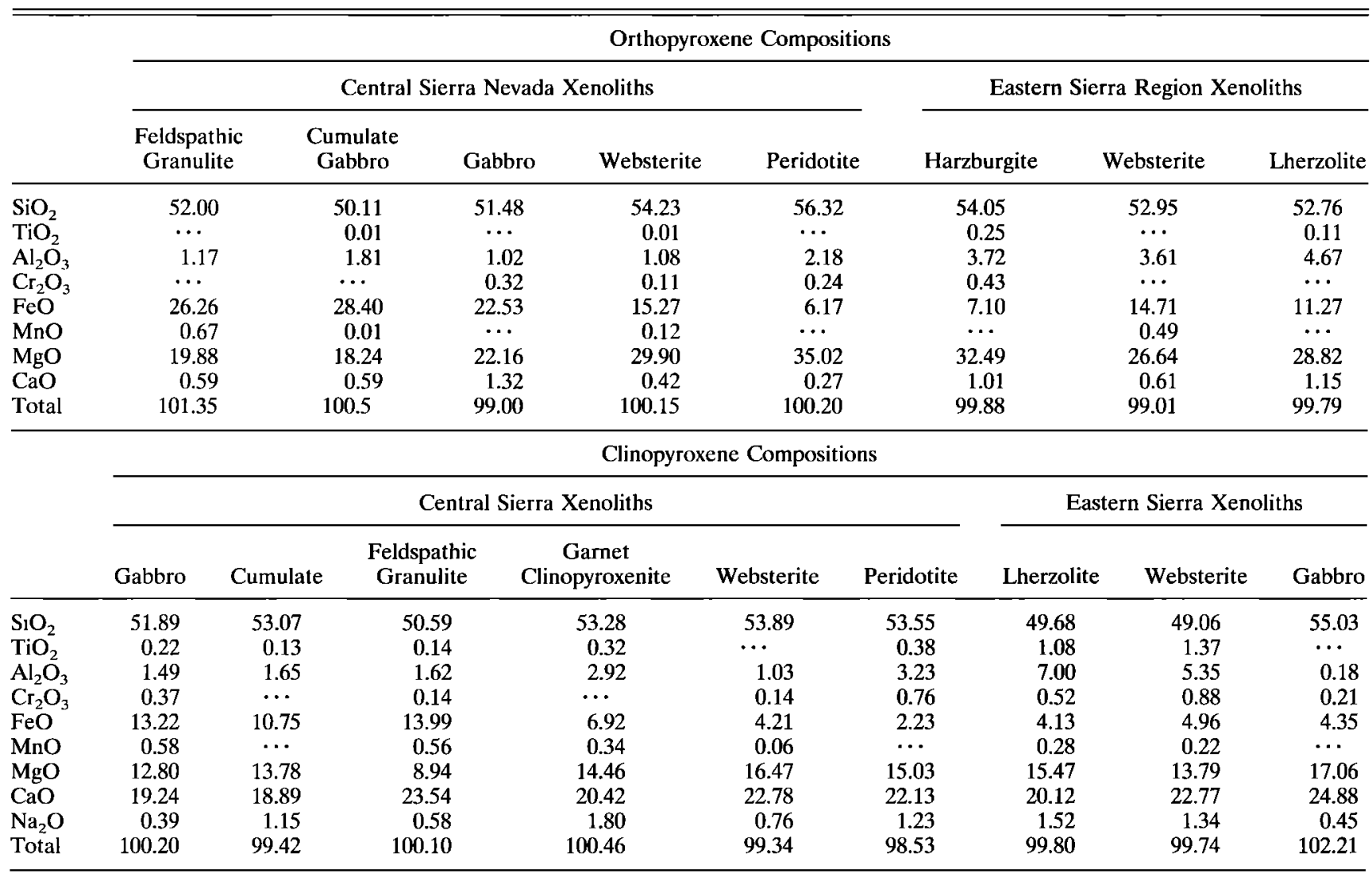

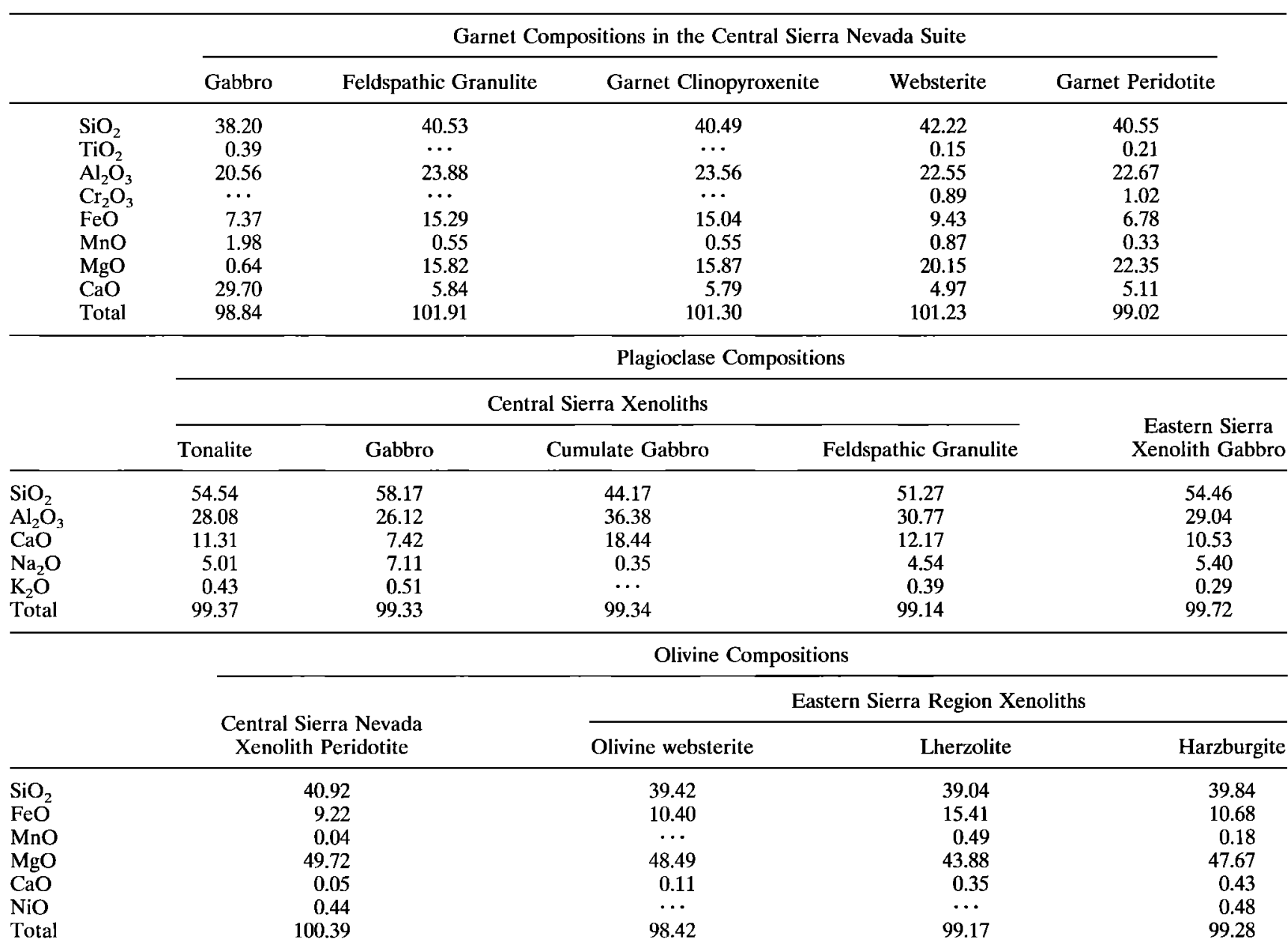


Table 3. (continued)

\begin{tabular}{|c|c|c|c|}
\hline & \multicolumn{3}{|c|}{ Spinel Compositions of the Eastern Sierra Region Xenoliths } \\
\hline & Lherzolite & Harzburgite & Spinel Websterite \\
\hline $\mathrm{TiO}_{2}$ & 0.50 & 0.29 & 1.21 \\
\hline $\mathrm{Al}_{2} \mathrm{O}_{3}$ & 53.14 & 44.71 & 53.46 \\
\hline $\mathrm{Cr}_{2} \mathrm{O}_{3}$ & 5.75 & 18.24 & 1.47 \\
\hline $\mathrm{FeO}$ & 21.97 & 16.62 & 24.49 \\
\hline $\mathrm{MnO}$ & 0.19 & 0.25 & 0.29 \\
\hline $\mathrm{MgO}$ & 18.09 & 18.64 & 16.62 \\
\hline $\mathrm{NiO}$ & $\ldots$ & 0.28 & 0.50 \\
\hline Total & 99.64 & 99.55 & 98.55 \\
\hline
\end{tabular}

$(\mathrm{Mg} /(\mathrm{Mg}+\mathrm{Fe}))$ in clinopyroxenes from both types of rocks. This suggests a common origin for the two groups.

Garnets have group B composition (Figure 3 [Coleman et al., 1965]). Mukhopadhyay [1989] observed similar compositions but with a wider range; some of his garnet compositions plot outside the Group B garnet field. Garnets do not exhibit chemical zoning except for the kelyphitization.

Peridotites and websterites. The chemistry of minerals from these rocks is also shown in Table 3. The very similar chemistry of the garnets, clinopyroxene, and orthopyroxene for both rock types is an argument for chemical equilibration be-

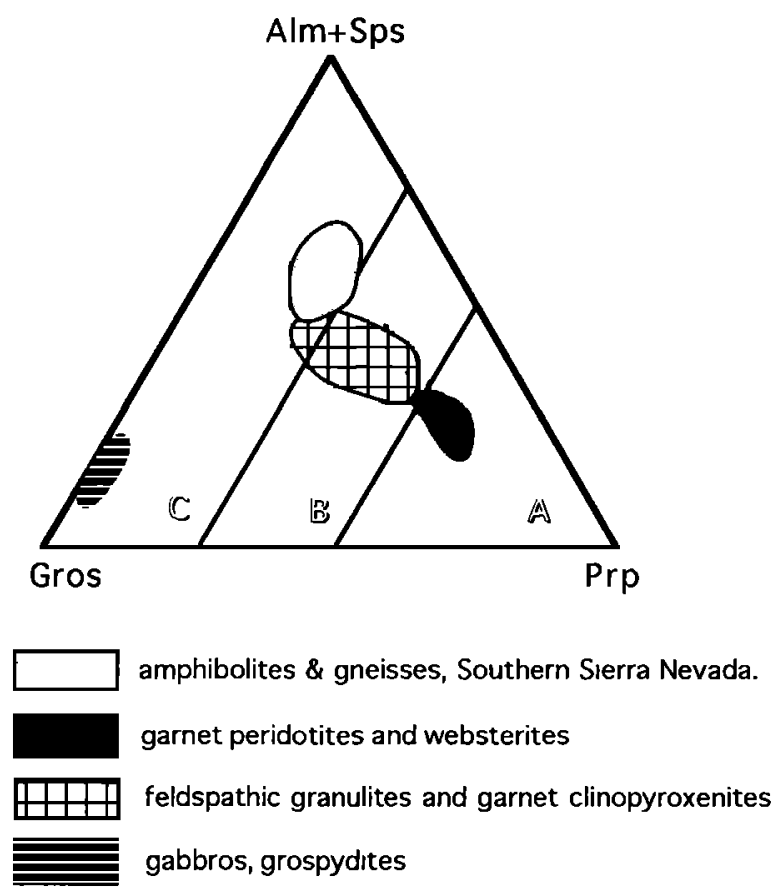

Figure 3. Summary of garnet compositions from various $\mathrm{Si}$ erra Nevada deep samples. Prp, pyrope component; Alm + Sps, almandine and spessartine component; and Gros, grossular component. Data on amphibolites and gneisses from the Tehachapi Mountains, Southern Sierra Nevada are from Pickett and Saleeby [1993]. Peridotites, websterites, granulites, clinopyroxenites, gabbros, and grospydites are xenoliths; their analyses are from this study, Mukhopadhyay [1989], and Dodge et al. [1986, 1988]. Fields A, B, and C are defined by Coleman et al. [1965]; field A is typical for garnets in kimberlites, field B corresponds to deep crustal garnets metamorphosed in the amphibolite or granulite facies, and field $\mathrm{C}$ corresponds to garnets from subduction-related complexes. tween them. Again, none of the clinopyroxenes are rich in jadeitic component. Garnets plot in the group A field of Coleman et al. [1965] resembling kimberlitic garnets (Figure 3). This is not surprising, since some of these rocks are unusually deep samples for alkali-basalt-hosted xenoliths (3.5 GPa).

\section{Eastern Sierra Nevada Suite}

No significant differences between the allotriomorphic and porphyroclastic type peridotites are apparent in the olivine and pyroxene phase chemistry (Table 3 ). Pyroxenites, olivine pyroxenites, lherzolites, and harzburgites exhibit very similar major element compositions for all major phases present. We describe below the mineral phases of the Eastern Sierra Region as a group.

Olivines from Eastern Sierra Region peridotites, olivine pyroxenites, and olivine xenocrysts are $\mathrm{Fo}_{87}-\mathrm{Fo}_{90}$. There is a significant variation in the $\mathrm{CaO}$ content in olivines $(0-0.8 \mathrm{wt}$ $\%$ ), indicative of a wide equilibration pressure range for these rocks [Kohler and Brey, 1990]. Zoning is rare in the olivines.

Orthopyroxene compositions are on average $\mathrm{En}_{88}$ and are relatively uniform in all lithologic types. Mineralogically, some of the magnesian pyroxenes are clinoenstatites with somewhat

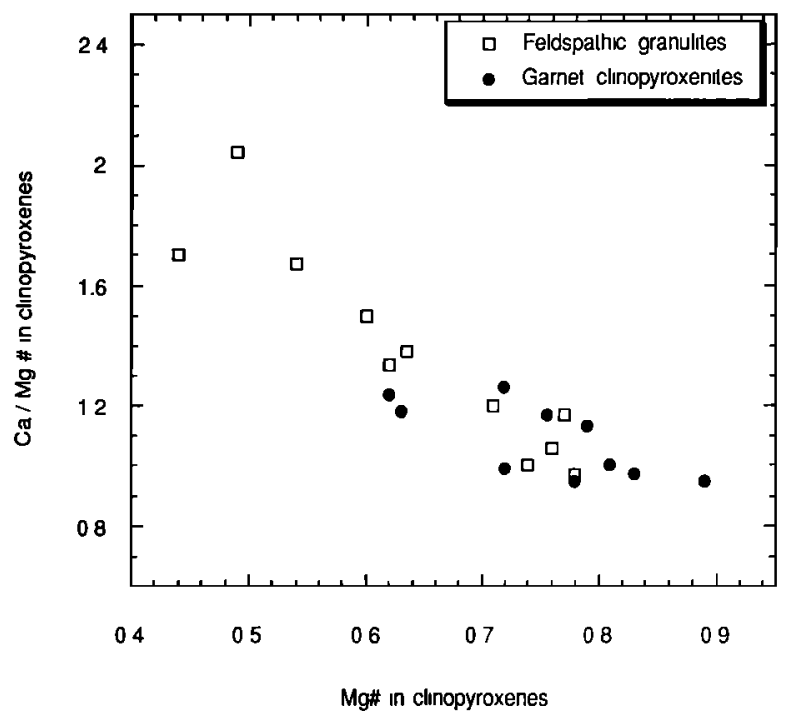

Figure 4. Quadrilateral components of clinopyroxenes in the Central Sierra Nevada feldspathic granulites and garnet clinopyroxenites. $\mathrm{Mg} \#$ represents the $\mathrm{Mg} /(\mathrm{Mg}+\mathrm{Fe})$ ratio in clinopyroxenes. The two petrographic groups display a coherent trend and significant overlap. 

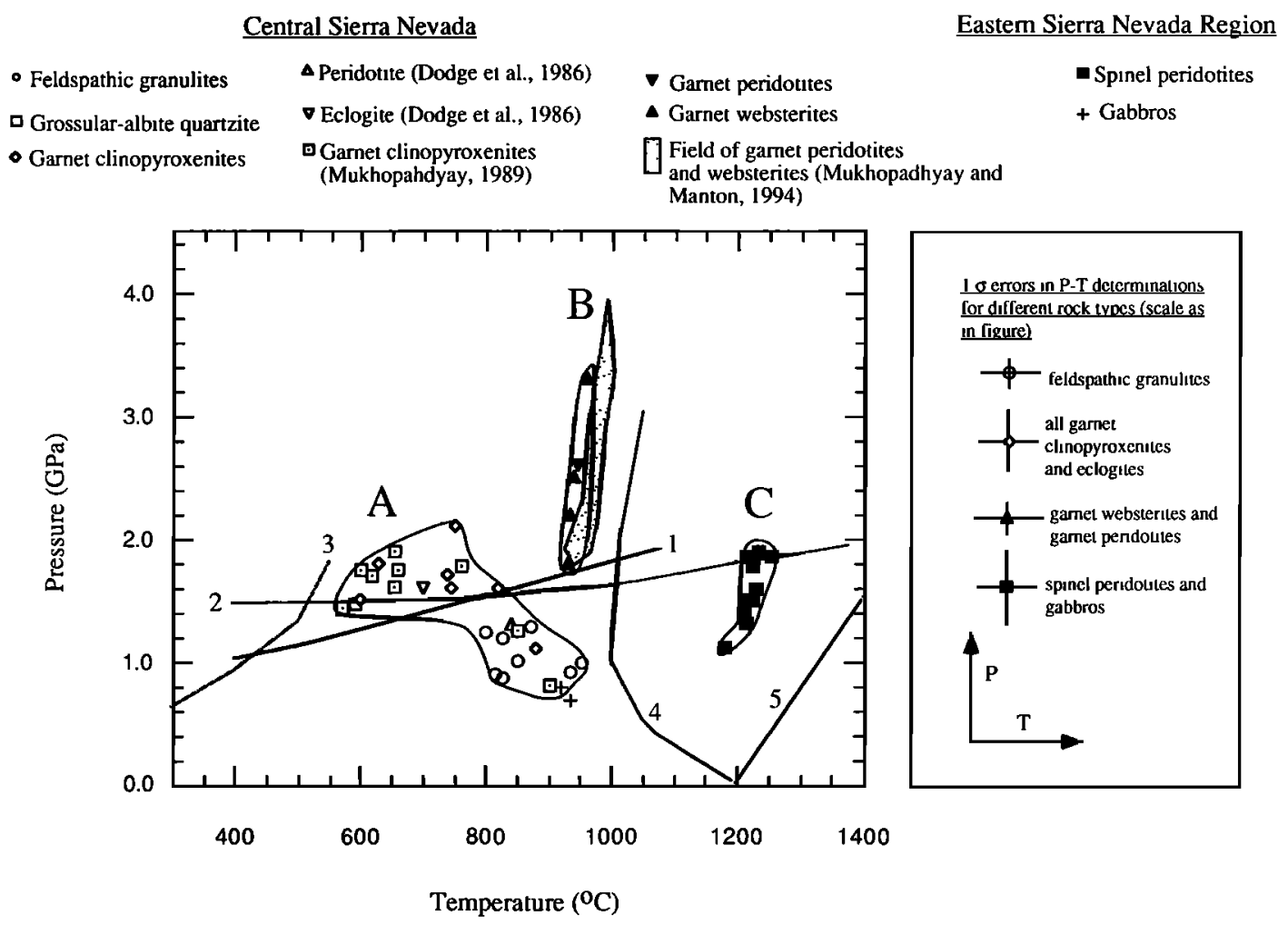

Figure 5. Equilibration temperatures and pressures for the Sierra Nevada xenoliths, including data from this study, Dodge et al. [1986, 1988], and Mukhopadhyay [1989]. Error bars include experimental and analytical uncertainties. Trends A, B, and C are explained in the text. Curve 1 represents the garnet breakdown reaction described in text (reaction (1)), calculated with the thermodynamic data set of Powell and Holland [1988]. Curve 2 is the spinel to garnet peridotite transition, based on the Basaltic Volcanism Study Project (BVSP) [1981], and curve 4 and 5 are the wet and dry solidi for mantle peridotite [BVSP, 1981]. Curve 3 is the low crustal geothermal gradient of the western Sierra Nevada, based on the heat flow measurements of Lachenbruch and Sass [1977], perhaps the typical thermal gradient of the entire Sierra Nevada for Cenozoic times, before the Basin and Range extension [see Dumitru, 1990].

higher $\mathrm{Al}$ and $\mathrm{Ti}$ contents, perhaps also a measure of a range of equilibration pressures.

Clinopyroxenes are on average $\mathrm{En}_{50} \mathrm{Fs}_{6} \mathrm{Wo}_{44}$, very similar to values reported by Beard and Glazner [1995]. The $\mathrm{Al}_{2} \mathrm{O}_{3}$ content varies from 6 to over $8 \mathrm{wt} \%$. Zoning is uncommon in the pyroxenes.

\section{Equilibration Pressures and Temperatures}

For many of the investigated xenoliths, we calculated the temperatures and pressures at which they equilibrated. We will describe below the thermometers and barometers that we used, the results of the pressure-temperature calculations, and the interpretation of the obtained geotherms (paleogeotherms and pseudogeotherms). The results are shown in Figure 5.

\section{Methods}

The equilibration temperatures for the granulites and garnet clinopyroxenites were determined using a single thermometer [Ellis and Green, 1979] and a single method of calculating the $\mathrm{Fe}^{3+}$ in the pyroxenes [Papike et al., 1974]. Several barometric calibrations are available for the feldspathic lower crustal lithologies (e.g., garnet-clinopyroxene-plagioclase-quartz). The equilibration pressures from different barometers applied on each feldspathic granulite sample [Perkins and Newton, 1981; Harley, 1984; Harley and Green, 1982; Perkins and Chipera,
1985] did not differ by more than $0.2 \mathrm{GPa}$. The equilibration pressures of the garnet clinopyroxenites were calculated using the Mukhopadhyay [1991a] barometer. To our data, we added thermobarometric results from Mukhopadhyay [1989] on the Big Creek and the Pick and Shovel garnet clinopyroxenites. In order to check consistency between the two types of barometers applied on the two different groups of rocks, we did two tests: (1) we calculated pressures of the clinopyroxene- and garnet-bearing feldspathic granulites using the Mukhopadhyay [1991a] barometer and compared these values with the much more reliable plagioclase-garnet-pyroxene-quartz barometers [e.g., Perkins and Newton, 1981], and (2) we calculated the $\mathrm{CaO} /(\mathrm{CaO}+\mathrm{MgO})$ ratios for garnets coexisting with pyroxenes for all xenoliths. The lower ratios of the garnet clinopyroxenites prove that they represent rocks that equilibrated at consistently higher pressures [Brey et al., 1986]. We observed that the pressures obtained on feldspathic samples with the Mukhopadhyay [1991a] barometer show consistently $\sim 0.1-0.2$ GPa higher pressure than the typical feldspathic granulite barometers [e.g., Newton and Perkins, 1982] and corrected the values obtained for garnet clinopyroxenites by subtracting 0.15 GPa from the values calculated using the Mukhopadhyay [1991a] calibration. The pressure data points in Figure 5 represent averages of the barometers for the feldspathic granulites and the Mukhopadhyay [1991a] corrected values for the garnet 
clinopyroxenites. We applied this correction also for the Big Creek and the Pick and Shovel data obtained by Mukhopadhyay [1989] using his calibration.

We analyzed four garnet websterites and one garnet peridotite and added the analyses on similar rocks from Mukhopadhyay and Manton [1994]. Temperatures are calculated with the Harley [1984] garnet-orthopyroxene thermometer for both the peridotites and websterites. Temperatures are $\sim 100^{\circ} \mathrm{C}$ higher when using the Ellis and Green [1979] calibration. Pressures were obtained by the Harley [1984] Al-in-orthopyroxene coexisting with garnet barometer. The difference between the results obtained with the Harley [1984] barometer on garnet websterites and the Mukhopadhyay [1991a] barometer on garnet clinopyroxenites was nonsystematic, as large as $0.35 \mathrm{GPa}$.

The temperatures for the spinel peridotites, spinel dunites, and olivine clinopyroxenites were determined using the following thermometers: two-pyroxene [Wells, 1977; Brey and Kohler, 1990], Ca-in-orthopyroxene, the partitioning of $\mathrm{Na}$ between the two pyroxenes (both described by Brey and Kohler [1990]), the $\mathrm{Mg}-\mathrm{Fe}$ exchange between olivine and spinel [Sack and Ghiorso, 1991]. All determined temperatures, including those lacking barometric data and not represented in Figure 5, fall between 1180 and $1250^{\circ} \mathrm{C}$. The pressures were determined on lherzolites and olivine clinopyroxenites using the Ca-in-olivine coexisting with clinopyroxene barometer [Kohler and Brey, 1990].

\section{Results}

The thermobarometric results are shown in Figure 5. Two pressure-temperature trends, "A" and "B," are characteristic for the Central Sierra Nevada and a third trend, "C," is characteristic for the Eastern Sierra Region.

\section{Interpretation}

Trend A. The results shown in Figure 5 reveal that the garnet clinopyroxenites show consistently higher equilibration pressures than the feldspathic granulites. A value of $\sim 1.2 \mathrm{GPa}$ would correspond to the transition from feldspar-bearing to feldspar-absent lithologies.

The negative slope in the PT diagram for trend A needs further explanation. One possible explanation is the presence of an inverted metamorphic gradient in the Sierra Nevada deep crust due to the presence of a shallow Cenozoic subducted slab, postulated by previous theoretical studies [e.g., Atwater and Molnar, 1973] and favored by thermochronologic [Dumitru, 1990] and geophysical data [Henyey and Lee, 1976]. If this is the case, the trend, although probably transient, would reflect $\mathrm{PT}$ conditions attained at some point in the Sierra Nevada. Such an interpretation would be bolstered if some or all of the eclogite facies xenoliths from the Central Sierra represent fragments of oceanic crust, as suggested by Dodge et al. [1986].

Alternatively, this slope might be an artifact of the conductive cooling undergone by the Sierra Nevada after the period of batholith generation. Deeper rocks in the suite cooled more slowly and can potentially equilibrate at lower temperatures [Frost and Chacko, 1989]. The effect should be significant because the deepest garnet clinopyroxenites equilibrated at 2 $\mathrm{GPa}$, almost twice as high a pressure as most of the feldspathic samples. Therefore they cooled $\sim 4$ times slower, based on the assumption of one-dimensional conductive cooling of the crust. We prefer the later hypothesis because all the current evidence on the origin of the rocks that define trend A [Ducea et al., 1995; Mukhopadhyay and Manton, 1994; Dodge et al., 1988] suggest a common, most likely batholithic origin for the garnet clinopyroxenites, gabbros, and mafic granulites. However, the very low temperatures recorded at deep levels in the batholith might overall be the result of the Cenozoic "slab refrigeration" advocated by Dumitru [1990].

Trend B. Trend B resembles a solid adiabat. Our results are remarkably similar to those of Mukhopadhyay and Manton [1994], confirming that the garnet websterites of the Central Sierra Nevada are the deepest rocks in the suite, associated with the mantle peridotites rather than with the crustal garnet clinopyroxenites.

Trend C. Trend C characterizes the Eastern Sierra Region for which both thermometric and barometric determinations were possible. It also has an adiabatic slope and is defined to depths as shallow as $35-40 \mathrm{~km}$, which corresponds to the base of the crust in the area. This implies that the convective mantle upper boundary is close to or at the base of the crust in the eastern Sierra-Owens Valley region. The error bars on this barometer are $\sim 0.3 \mathrm{GPa}$. Nevertheless, the consistent pressure variation at nearly constant temperature suggests that the adiabatic, asthenospheric-like slope in PT space is probably real.

The xenolith thermometry also suggests a late Cenozoic lateral temperature variation in the sub-Sierra upper mantle (trends $\mathrm{B}$ and $\mathrm{C}$ ). The recorded difference in the xenolith assemblage is $\sim 250^{\circ} \mathrm{C}$, but this can be higher than the real lateral temperature difference in the Sierra Nevada lithosphere because it was recorded at different times.

One important problem with the thermobarometry is the timing of the equilibration. Geochronometric work is in progress. As a working model based on the geologic history of the Sierra Nevada and adjacent Basin and Range, we hypothesize that trend $\mathrm{A}$ is a cooling slope for the deep batholithic rocks and was probably attained between 100 and $80 \mathrm{Ma}$. This hypothesis is consistent with a $100 \mathrm{Ma}$ zircon $\mathrm{U} / \mathrm{Pb}$ data from a granulite xenolith from Chinese Peak [Dodge et al., 1986]. Trends $\mathrm{B}$ and $\mathrm{C}$ are possibly related to the young (post $20 \mathrm{Ma}$ ) extension in the Basin and Range and formation of the eastern Sierra Nevada range front. Lack of timing information for the described trends leaves several unanswered questions; for example, if the rocks forming trend $A$ were at their equilibration depths during establishment of trend $B$, why did they fail to reequilibrate at higher temperatures?

Another potential problem with the high temperatures of trends $B$ and $C$ is to what extent they have been influenced by the presence of magmas similar to the xenoliths' hosts? Are we looking at PT trends indeed representative for the Sierra Nevada mantle at a regional scale or at an uppermost mantle that was anomalous because of the very existence of magmatism? For example, the temperatures of trend B imply a relatively high heat flow in recent past, in contrast with present-day measurements of heat flow in the same region [Lachenbruch and Sass, 1977]. Yet the differences between the mantle compositional properties in the central versus the eastern part of the range exist and they need to be interpreted.

\section{Composition and Structure of the Sierra Nevada}

We will use the petrographic and thermobarometric results to constrain (1) the composition and crustal thickness of the Sierra Nevada during batholith generation, (2) the present-day composition and crustal thickness, and (3) the position of the 
lithosphere-asthenosphere boundary during late Cenozoic time beneath the Sierra Nevada.

\section{Before Basin and Range Extension}

The central region of the Sierra Nevada batholith is exposed to an average crustal depth of $\sim 10 \mathrm{~km}$ [Ague and Brimhall, 1988] and has an average tonalitic composition for the upper to mid-crustal levels [Saleeby, 1990], typical of the Circum-Pacific Cordilleran-type batholiths.

The composition of the lower continental crust is a subject of intense controversy [e.g., Kay and Kay, 1986; Meissner, 1986; Rudnick and Taylor, 1987; Hanchar et al., 1994] for the southwestern United States. Geochemical calculations based on planetary models and evidence from crustal xenoliths point to a mafic composition ( $\sim 48-50$ wt \% $\mathrm{SiO}_{2}$ [Rudnick, 1993; Griffin and O'Reilly, 1986], while exposed lower crustal terranes suggest a more intermediate, andesitic composition (up to 55-60 wt \% $\mathrm{SiO}_{2}$ [Taylor and McLennan, 1985; Saleeby, 1990]). Several hypotheses have been proposed to explain this difference: mafic compositions may be more resistant as xenoliths; exposed deep crustal terrains may represent anomalously buoyant lower crust; or since exposed lower crustal fragments are often Precambrian in age, they might be representative of a different, more silicic lower crustal composition of the early Earth [e.g., Rudnick, 1993].

In the case of the deep exposure of the southernmost Sierra Nevada, tonalite $\left(\sim 55\right.$ wt $\left.\% \mathrm{SiO}_{2}\right)$ with subordinate maficultramafic cumulates of the primary batholithic crust equilibrated from 27 - to $35-\mathrm{km}$ depth, equivalent to pressures of 0.8-1 GPa [Pickett and Saleeby, 1993]. We note that the mafic feldspathic granulite xenoliths of the Central Sierra Nevada suite yield pressures of 0.8-1.2 GPa, which overlap this depth range. Additionally, there are tonalite xenoliths from the Central Sierra Nevada suite which could have likewise formed at pressures of $0.8-1 \mathrm{GPa}$, but useful barometric indicators have yet to be found. Overall, the average composition of the xenoliths that equilibrated at $\sim 1 \mathrm{GPa}$ in the Sierra suites is more mafic than the average xenoliths equilibrated at $\sim 1 \mathrm{GPa}$ in the Mojave desert (Figure 1) [Hanchar et al., 1994].

We tentatively interpret the above relations to indicate that at $\sim 1 \mathrm{GPa}$ the primary batholithic composition graded upward from predominantly mafic (48-50 wt $\% \mathrm{SiO}_{2}$ ) to predominantly tonalitic (55-60 wt \% $\left.\mathrm{SiO}_{2}\right)$. The Central Sierra Nevada xenolith data further suggest that the deep mafic batholith extends or extended downward to $\sim 65-70 \mathrm{~km}$ (pressures of 2 $\mathrm{GPa}$ ). At the time of xenolith entrapment, depths corresponding to pressures greater than $1.2 \mathrm{GPa}$ within this layer were in the eclogitic facies. The rocks are garnet clinopyroxenites which fall in the group B eclogites of Coleman et al. [1965] and are different from the eclogites described in kimberlites and subduction complexes. They resemble granulite-facies to eclogite-facies assemblages, and some may be high-pressure magmatic eclogitic assemblages [Mukhopadhyay, 1991b]. These eclogites are mafic rocks, part of the petrologically defined crust, but are also dense and have high seismic velocities yielding properties of the seismic mantle. The Moho discontinuity would correspond in these situations with the basalt-eclogite transition, a phase change rather than a chemical boundary [Wyllie, 1963; Ito and Kennedy, 1970; Dewey et al., 1993].

Preliminary trace element [Ducea et al., 1995] and isotopic [Mukhopadhyay, 1989] data on the feldspathic granulites and the garnet clinopyroxenites support the above proposition that these assemblages represent a coherent mafic igneous proto- lith suite directly related to the overlying batholith. A close relationship between the feldspar-free and feldspar-bearing deep mafic rocks is further suggested by the recovery of a few composite granulite-garnet clinopyroxenite layered xenoliths [Dodge et al., 1988].

A bulk mafic composition of the lower crustal xenoliths would undergo a basalt-eclogite transition following the garnet breakdown reaction:

pyrope + grossular $=$ anorthite +2 diopside + spinel

This univariant reaction, although a simplified one, uses the rough composition of the garnets in the xenoliths. We calculated the PT position of this univariant curve (labeled " 1 " in Figure 5) using the thermodynamic data set of Powell and Holland [1988]. The calculated PTs from xenoliths are consistent with the reaction (1). It should be noticed that during high heat flow periods, such as batholith formation, little if any mafic crust would be in eclogite facies down to $\sim 70-\mathrm{km}$ depths. In contrast, the extremely low heat flow regime which followed batholith generation in the Cenozoic [Dumitru, 1990] strongly favors eclogitic conditions for the deep mafic batholithic rocks, below $\sim 35 \mathrm{~km}$ (Figure 6).

Given the rapid increase in cooling rates following the Cretaceous batholith emplacement [Renne et al., 1993], the batholith exhumation must have been rapid and of the order of $0.2-0.3 \mathrm{GPa}$. This is further supported by the thick Cretaceous stratigraphy with a batholithic source in the Great Valley [Mansfield, 1979] and leaves very little exhumation as a result of the commonly presumed late Cenozoic uplift. From the above observations, we can speculate about the original thickness of the Sierra Nevada batholithic crust: the abundant growth of garnet in the lower crustal rocks took place during cooling of the batholith, most likely after the initial rapid exhumation of the batholith which followed its emplacement. Therefore, to the pressures recorded, we could add $\sim 0.3 \mathrm{GPa}$, the average pressure of exposure in the batholith today [Ague and Brimhall, 1988], which corresponds to $\sim 11$ - to 12-km erosional removal from its top. The implied crustal thickness of $\sim 75-80 \mathrm{~km}$ would be very similar to the crustal thickness of the modern day Andes [Isacks, 1988]. Given the coherency of the surface batholith, we will assume that this primary batholith "thickness" applies to the entire Sierra Nevada crustal section before extension (Figure 6).

\section{Modern Crustal Thickness}

The modern Sierra Nevada has a thin, $\sim 35-\mathrm{km}$-thick crust (Figure 7) [Wernicke et al., 1996], which is on average only $5 \mathrm{~km}$ thicker than the Basin and Range crust [Mooney and Weaver, 1989] (also, S. Ruppert and M. M. Fliedner, Crustal structure and thickness of the Southern Sierra Nevada from seismic refraction profiles, submitted to Geophysical Research Letters, 1995; hereinafter referred to as submitted manuscript, 1995). The seismic results show a slight westward thickening (35-42 $\mathrm{km}$ ) within the Sierra Nevada and also a change from a sharp Moho in the east, beneath the Sierra Nevada crest to a diffuse Moho under the western side of the range (S. Ruppert and $M$. M. Fliedner, submitted manuscript, 1995). The recorded crustal thickness and the sharpness of Moho are in agreement with the transition from mafic to ultramafic assemblages found in Eastern Sierra Region xenoliths and also with the granuliteeclogite facies transition suggested by the Central Sierra Nevada xenolith petrography and thermobarometry. Therefore 
a

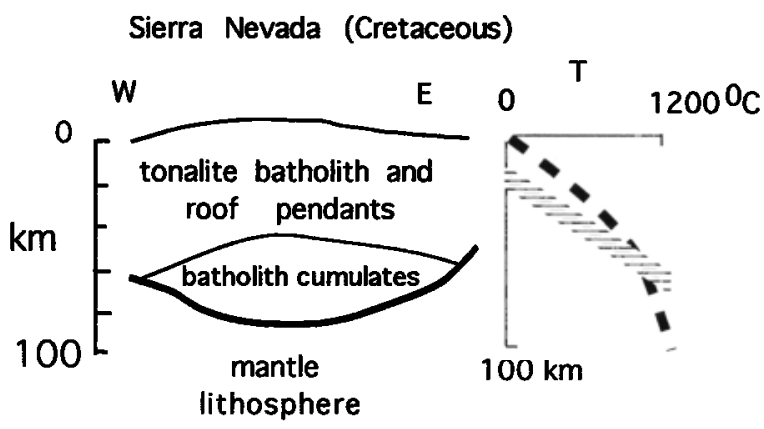

b

Sierra Nevada (Cenozoic, pre-Basin and Range extension)

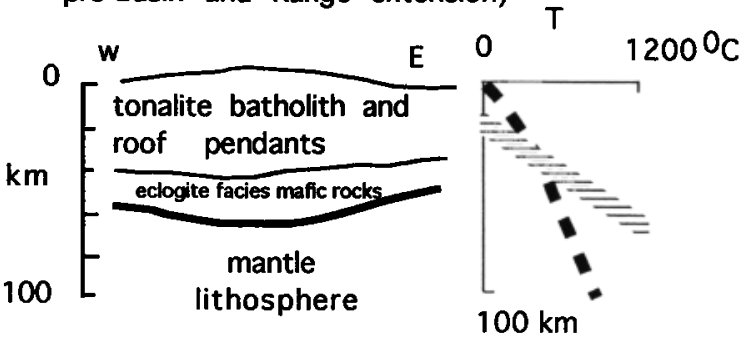

$$
\begin{aligned}
& \text { crust-mantle boundary } \\
& \text { - thermal gradient } \\
& \text { basalt-eclogite phase change }
\end{aligned}
$$

Figure 6. Schematic cross section (not at scale) of the composition and structure of the Sierra Nevada (a) at the time of batholith formation ( $\sim$ Cretaceous) and (b) during the Cenozoic, but prior to the extension of the westernmost Basin and Range. The figure emphasizes the existence of a thick $(\sim 80 \mathrm{~km})$ crust, generated mainly during batholith-related magmatism. Ten kilometers of the crustal section were lost during the late Cretaceous rapid exhumation of the batholith [e.g., Renne et al., 1993]. The temperature-depth schematic diagrams show how an average basalt-eclogite univariant curve would intersect the geothermal gradients typical for the Sierra Nevada during batholith generation and the low Cenozoic heat flow, respectively. The mafic "root" of the batholith was probably metamorphosed in the eclogite facies for most of the Cenozoic.

the recorded Moho can be a phase change in the western side of the batholith and a chemical change on the eastern side. The two important implications of these observations are (1) the seismologically defined crust under the western-central Sierra Nevada may be $\sim 25 \mathrm{~km}$ thinner than the petrologically defined crust, and (2) the lowermost batholithic crust has been re- placed by peridotitic upper mantle rocks under the high part of the range, the eastern Sierra Nevada (Figure 7). Possible mechanisms of removal will be addressed below. Recent investigations of xenolith-bearing volcanics younger than $3.5 \mathrm{Ma}$ from the central Sierra Nevada (M. N. Ducea and J. B. Saleeby, unpublished data, 1995) show that garnet is absent in

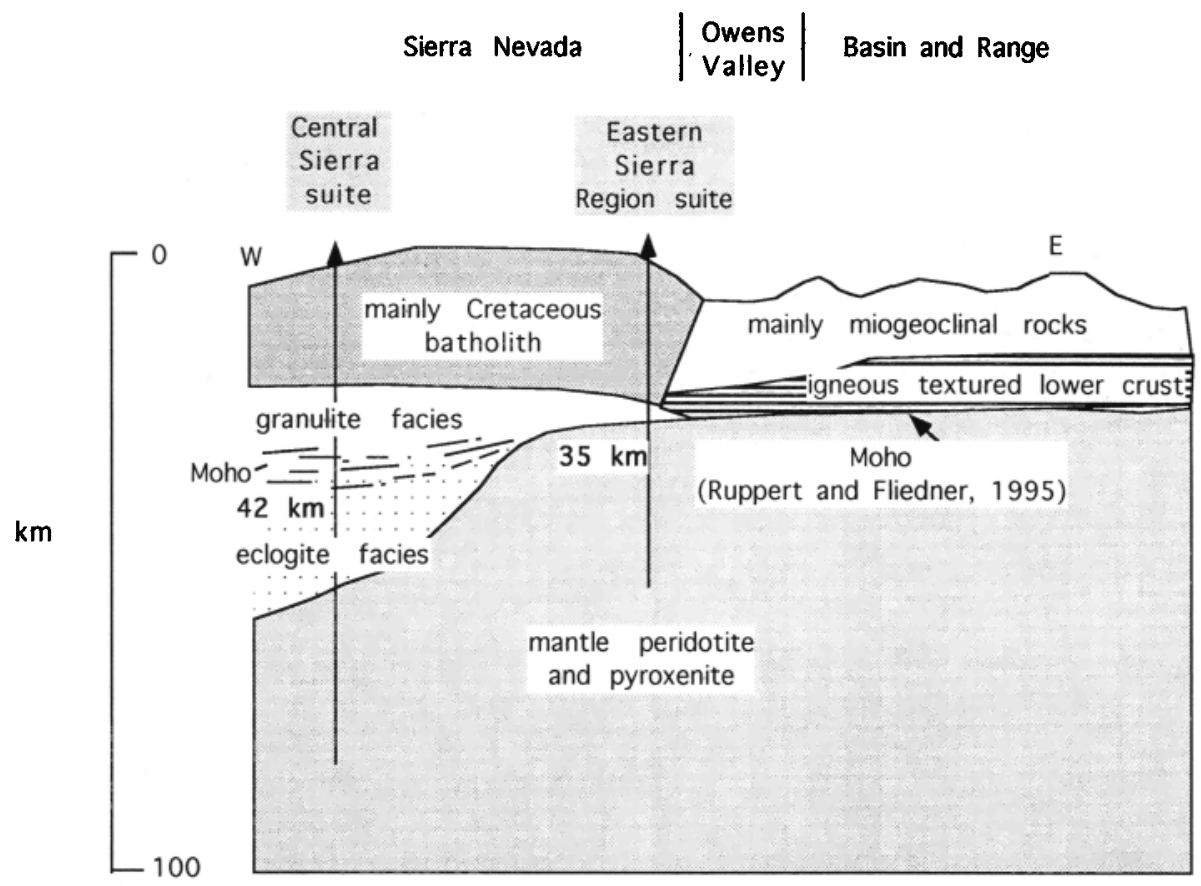

Figure 7. Schematic cross section (not to scale) of the recent to present-day composition and structure of the Sierra Nevada. The depth and sharpness of Moho are based on the results of the Sierra Nevada Continental Dynamics Project seismic refraction study (S. Ruppert and M. M. Fliedner, submitted manuscript, 1995). It is possible that the mafic lower crust was also removed from the western Sierra Nevada. 
the lower crustal lithologies. It is therefore possible that the lower crust was removed from the central Sierra Nevada, as well, since the time when the xenoliths reported in this study were sampled by their host $\sim$ Miocene volcanics.

\section{Lithosphere-Asthenosphere Boundary}

Several geophysical studies of the Sierra Nevada [e.g., Crough and Thompson, 1977; Jones, 1987] postulate a shallow lithosphere-asthenosphere boundary beneath the easternmost part of the range. The thermobarometry of the Eastern Sierra Region xenoliths investigated in this study confirms this hypothesis. Although the barometry on garnet-absent lithologies of the Eastern Sierra Region is subject to large errors, there is a $\sim 1 \mathrm{GPa}$ range in the spinel lherzolites, and all samples show remarkably similar temperatures $\left(1180^{\circ}-1250^{\circ} \mathrm{C}\right)$. A solid adiabatic geotherm can be defined 35-37 km ( 1 GPa) beneath the Owens Valley. The recrystallization textures observed in many of the Eastern Sierra Region xenoliths suggest a dynamic evolution of the Eastern Sierra Region upper mantle. These observations are consistent with having the convective upper mantle at the base of the crust beneath the eastern side of the Sierra Nevada and Owens Valley. The juxtaposition of hot asthenospheric mantle with the lower crust in the Owens Valley can be responsible for the significant fraction of crustal melts identified throughout the Owens Valley, including the Long Valley caldera.

The Central Sierra Nevada peridotites and garnet websterites also define an adiabat (Figure 5), but the temperatures are around $950^{\circ}-1000^{\circ} \mathrm{C}$, which is $\sim 250^{\circ} \mathrm{C}$ less than the Eastern Sierra Region adiabat.

One possible explanation for this adiabat is that the mantle beneath the Central Sierra Nevada behaved as a convective domain at the time of xenolith entrapment. This hypothesis is based on the magnitude of extension that occurred since Miocene in the area to the east. However, the chemical and isotopic signature of the ultramafic xenoliths and their host basalts from both the Central Sierra Nevada and the Eastern Sierra Region is characteristic of mantle lithosphere [Mukhopadhyay and Manton, 1994; Beard and Glazner, 1995]. In particular, if we were to postulate the presence of the convective upper mantle as shallow as $\sim 65 \mathrm{~km}$ in the Central Sierra Nevada and $\sim 35 \mathrm{~km}$ in the Eastern Sierra Region, it should be pointed out that this asthenosphere-like behavior is a smallscale convection [Buck, 1985] of the old, thinned mantle lithosphere, in response to extension. However, an adiabatic gradient in a convective upper mantle is unlikely at $\sim 950^{\circ} \mathrm{C}$, that is, beneath the Central Sierra (trend B).

The adiabatic-like trend $B$ could, alternatively, be an artifact produced by side heating from the Basin and Range. In order to test this possibility, we modeled the temperature distribution in the Sierra Nevada cold upper mantle and the changes associated with the juxtaposition of hot, asthenospheric mantle to the east. We solved the transient, two-dimensional heat conduction equation:

$$
\frac{\partial^{2} T}{\partial x^{2}}+\frac{\partial^{2} T}{\partial y^{2}}-\frac{1}{\kappa} \frac{\partial T}{\partial t}+\frac{A_{0}}{K}=0
$$

for a rectangular slab representing a west-east cross section through the Sierra Nevada (Figure 8), down to $150 \mathrm{~km}$, where $T$ is temperature, $t$ is time, $x$ is horizontal distance, $y$ is depth, and $A_{0}$ is heat production in the crust. As boundary conditions, we used a temperature of $15^{\circ} \mathrm{C}$ at the surface $(y=0)$, a mantle heat flux $\left(q_{m}\right)$ of $16 \mathrm{~mW} / \mathrm{m}^{3}$ [Lachenbruch and Sass, 1977], and a constant, high thermal gradient at the eastern edge of the rectangle, such that temperatures of $1250^{\circ} \mathrm{C}$ are attained at a depth of $65 \mathrm{~km}$, which is also set to be the lithosphere-asthenosphere boundary. The initial condition is represented in this problem by the low, conductive thermal gradient deduced from today's heat flow measurements in the western Sierra Nevada [Lachenbruch and Sass, 1977], applied throughout the Sierra Nevada block. The problem was solved by the finite difference method using a computer program by $S$. Tulaczyk (Caltech). Results for the change in the temperature distribution after 4 and $10 \mathrm{~m} . \mathrm{y}$. are shown in Figure 8. The eastern edge boundary condition is somewhat unrealistic because it is more likely that the high heat flows at the edge were attained gradually. The general trends shown in Figure 8 will, however, be similar. The results show that it is very likely that heating during a reasonable timescale of 10 m.y. can produce an adiabatic-like temperature distribution in the Sierra Nevada lithosphere without any convection being involved in the top $150 \mathrm{~km}$ beneath the Sierra Nevada.

\section{Buoyancy Sources and Lithospheric Dynamics}

As demonstrated above, the present-day Sierra Nevada has a thin crust. The crustal thickness is insufficient to hold the mountain range's elevations. We will define below the "missing root problem" for the Sierra Nevada [see also Jones et al., 1994; Wernicke et al., 1995]. Then our results from xenolith petrography and thermobarometry will be used to constrain the possible buoyancy sources for the "unrooted" Sierra Nevada. In order to assess the buoyancy of the Sierra Nevada, the effects of lithospheric thinning and melting as well as crustal thinning must be considered.

\section{Missing Root Problem}

The Sierra Nevada crustal root is defined here as the difference between Sierra Nevada and western Basin and Range crustal thickness. As previously mentioned, recent seismic refraction experiments show an average crustal root of $\sim 5 \mathrm{~km}$ for the Southern Sierra [Wernicke et al., 1996]. The xenolith data presented here are consistent with a shallow Moho underneath the Sierra Nevada. Regardless of the nature of the crustmantle boundary beneath the Sierra Nevada and westernmost Basin and Range, the thin, low-density (low seismic velocity) crustal material is insufficient to hold up the 2800 -m average elevation mountain range, $1800 \mathrm{~m}$ higher than the neighboring western Basin and Range [Wernicke et al., 1996], assuming isostatic equilibrium (Airy equilibrium). If the average lower crust in the Sierra Nevada above $35 \mathrm{~km}$ is tonalitic $(\rho=2800$ $\mathrm{kg} / \mathrm{m}^{3}$ ) and the Basin and Range deep crust is basaltic ( $\rho=$ $3000-3100 \mathrm{~kg} / \mathrm{m}^{3}$ ), only $15-20 \mathrm{~km}$ of thicker crust in the Sierra Nevada than in the Basin and Range would be required to support the mountain range's elevation (Figure 9a). A mafic lower crust in the Sierra Nevada would require $20-25 \mathrm{~km}$ of crustal root, and the elevation must be explained mainly by localized mantle buoyancy beneath the Sierra Nevada. These figures are based on the assumption of a constant mantle density of $3300 \mathrm{~kg} / \mathrm{m}^{3}$.

Jones et al. [1994] showed that lateral density variations within the Sierra Nevada crust (crustal Pratt equilibrium) are also insufficient to create the large elevation differences (Figure $9 \mathrm{~b}$ ).

None of these scenarios for crustal composition can explain 


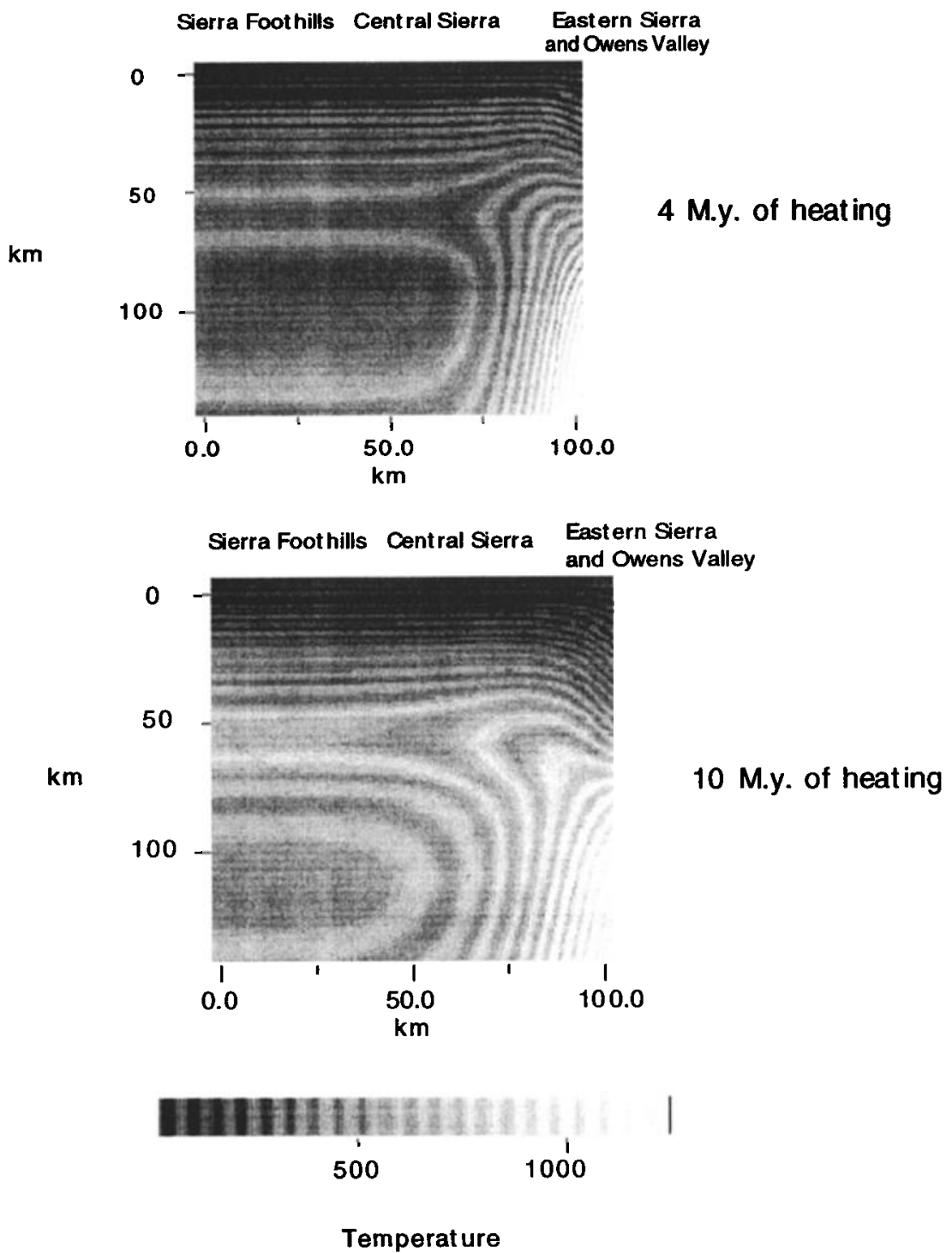

Figure 8. Changes in the Sierra Nevada thermal gradient due to the juxtaposition of hot, asthenospheric mantle to the east, in the westernmost Basin and Range. The figure shows the solution to the transient, two-dimensional heat conduction equation ((2), see text). The horizontal length in the problem is $100 \mathrm{~km}($ the label 100.0 corresponds to Owens Valley). The vertical dimension in the problem is $150 \mathrm{~km}$ ( 0 corresponds to the surface). The initial condition is a low thermal gradient [Dumitru, 1990], applied throughout the rectangular slab. A boundary kept at high and constant thermal gradient $\left(1200^{\circ} \mathrm{C}\right.$ at $\left.65 \mathrm{~km}\right)$ is imposed on the eastern margin. The changes in the thermal gradient in the slab (shown here for 4 and $10 \mathrm{~m}$.y. after the juxtaposition of the hot boundary) can generate an adiabatic-like temperature gradient in the slab. This general trend holds true when this slab (which stands for cold Sierra Nevada lithosphere) is thinner.

the Sierra Nevada elevations. Ten to $20 \mathrm{~km}$ of root are "missing," and a support mechanism within the seismologically defined upper mantle must be found (Figure 9c). The Sierra Nevada seems to be a typical rift shoulder, and an elevation support mechanism that incorporates extension-related processes must be found.

\section{Lithospheric Thinning and Melting}

Extensional processes tend to thin the lithosphere by replacing it with hotter, asthenospheric material. The decrease in density due to replacement of lithosphere with asthenosphere due to increased temperature is given by $\phi$ :

$$
\phi=\rho_{h} / \rho_{c}=1 /(1+\alpha \Delta T)
$$

where $\rho_{h}$ is asthenosphere density, $\rho_{c}$ is lithosphere density, $\alpha$ is volumetric coefficient of thermal expansion, and $\Delta T$ is the temperature difference between asthenosphere and lithosphere. For a $250^{\circ} \mathrm{C}$ temperature difference (shown by xenoliths) and $\alpha=3.4 \times 10^{-5}{ }^{\circ} \mathrm{C}^{-1}$ [Cochran, 1982; White and McKenzie, 1989], replacement of only $33 \mathrm{~km}$ of cold with hot material can account for a $3000-\mathrm{m}$ difference in elevation. If the $\Delta T$ is smaller, say, $150^{\circ} \mathrm{C}$, or even $100^{\circ} \mathrm{C}, 60 \mathrm{~km}$ or $82 \mathrm{~km}$ of lithosphere, respectively, must be removed. If this is combined with the use of smaller $\alpha$, as much as $150 \mathrm{~km}$ of lithosphere must be removed in order to support the average 2800 to $3000-\mathrm{m}$ elevations.

Therefore the dynamic lithosphere-asthenosphere replace- 

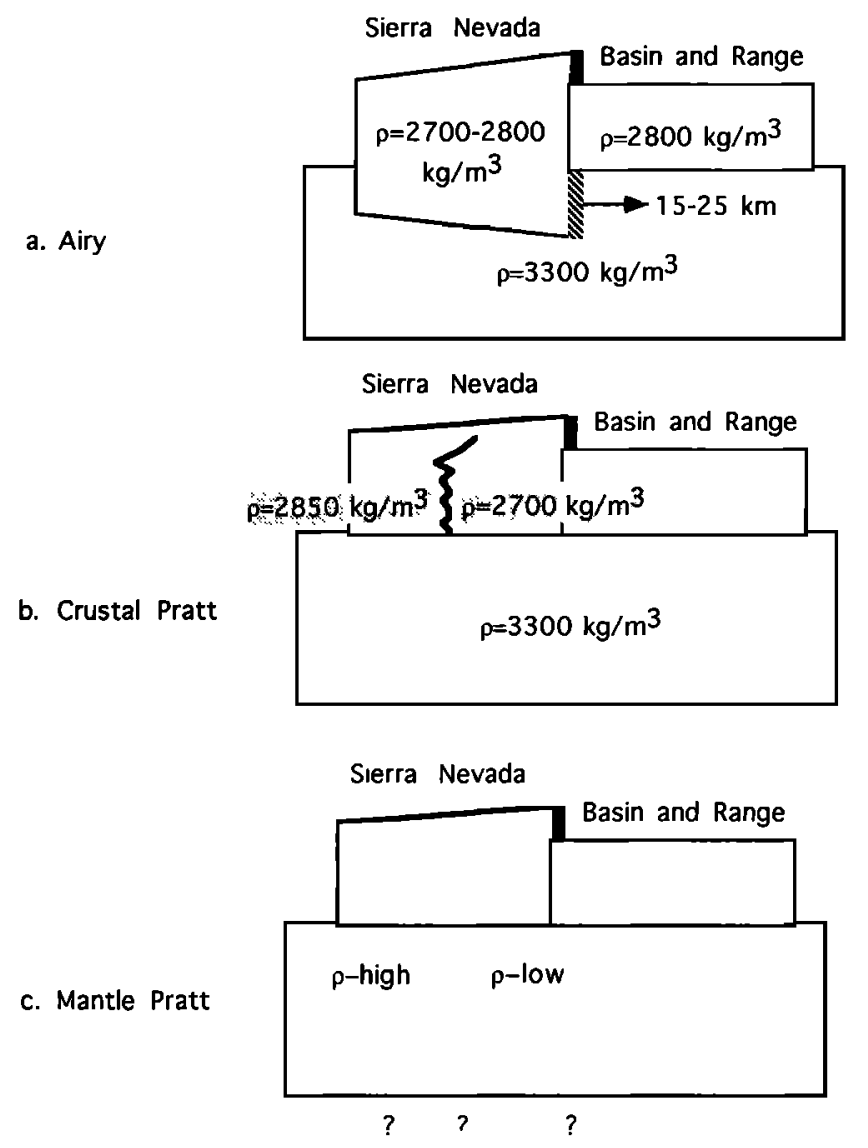

$2000 \mathrm{~m}$ average elevation difference

Figure 9. Possible support mechanisms for the present-day Sierra Nevada topography (modified after Jones et al. [1994]). (a) An Airy model would require $\sim 15-25 \mathrm{~km}$ of low-density "root"; (b) a crustal Pratt model cannot explain the topography (see text); (c) a mantle Pratt model, involving a lowerdensity mantle beneath the eastern part of the range than the western part of the range, is supported by xenolith data. The overall high topography of the Sierra Nevada + Basin and Range compared to the area to the west (Great Valley, see Figure 1) can be explained by lithospheric mantle thinning.

ment process would in general hold the Sierra Nevada approximately $3000 \mathrm{~m}$ higher than the neighboring Great Valley to the west (sea level mean elevations) if $\sim 35-150 \mathrm{~km}$ of lithosphere was removed from beneath the Sierra Nevada and further to the east.

Partial melting of the upper mantle beneath the eastern Sierra Nevada during asthenospheric upwelling is another potential source of buoyancy [McKenzie and Bickle, 1988].

The upper mantle beneath the Eastern Sierra has undergone partial melting with the generation of alkali basalts and tholeiitic basalts in the Big Pine Volcanic Field [Ormerod et al., 1988], the Coso Region, and the Long Valley Region [Luedke and Smith, 1981]. There is also strong evidence for the presence of fluids, including melt inclusions not related to the host basalts in almost all Eastern Sierra Region xenoliths (M. N. Ducea and J. B. Saleeby, unpublished data, 1995) and high electrical conductivity of the eastern Sierra Nevada upper mantle (S. K. Park et al., Magnetotelluric evidence of mantle thinning beneath the Sierra Nevada, submitted to Journal of Geophysical Research, 1995). However, melting may only be of second-order importance for the Sierra Nevada support mechanism problem. For the recorded $\Delta T$, small stretching factors (compared to the oceanic lithosphere case) and initial lithospheric thickness of $\leq 200 \mathrm{~km}$, such as in young orogenic regions, the melt "thickness" is negligible and produces at most $0.3 \mathrm{~km}$ of uplift [White and McKenzie, 1989].

\section{Crustal Thinning}

In general, crustal thinning produces subsidence. We will show that in the particular case of the Sierra Nevada, this might not be true because thinning involves the removal of a very dense (eclogite facies) lowermost crust by lower-density material. We want to estimate the net result of crustal thinning in this case. The magnitude of the subsidence generated by the thinning alone and the uplift generated by lowering the density of the lithospheric column will be estimated below.

The amount of crustal thinning is most easily quantified by the stretching factor $(\beta)$. The $\beta$ factor is based on the assumption of instantaneous extension of vertical columns of lithosphere and crust by equal amounts and passive response of the asthenospheric mantle which upwells to maintain isostatic equilibrium. When a vertical column of the lithosphere is stretched by a factor of $\beta$, it thins to $1 / \beta$ times its original thickness [McKenzie, 1978]. If the Sierra Nevada is viewed as a rigid block which did not experience crustal thinning ( $\beta_{\text {Sierra }}$ $\sim 1$ ), the uplift-generating effects of mantle lithosphere thinning described in the previous section can hold the mountain range at its current elevations. A $2000-\mathrm{m}$ difference in elevation between the Sierra Nevada and the Basin and Range would be predicted by the White and McKenzie [1989] pure shear stretching model solely based on the increase of the $\beta$ factor from 1 for the Sierra Nevada to $\sim 2.5$ for the Basin and Range. The type of lithospheric stretching is an important factor in determining the magnitude of the effect. A simple

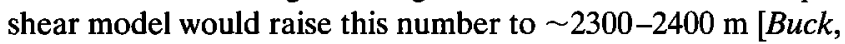
1985].

At the edge of the Sierra Nevada, in Owens Valley, mantle peridotites are found as shallow as $35 \mathrm{~km}$, strongly favoring the hypothesis of complete lower batholithic crust removal. We think that this is strong evidence for significant crustal thinning, by a factor of at least 2 , beneath the highest part of the Sierra Nevada.

Mass conservation in the adjacent Basin and Range also requires the involvement of the Sierra Nevada in the significant thinning process [Wernicke, 1992]. Wernicke et al. [1996] predict an average $\beta$ of $\sim 2$ for the Sierra Nevada. If this is the case, and about $30 \mathrm{~km}$ of lower crustal Sierra was removed in the process, an unusually thick lithosphere $(\sim 250-300 \mathrm{~km})$ must have been replaced with asthenosphere if we are to explain the buoyancy by this process. Also, the small $\beta_{\text {Sierra }}-$ $\beta_{\text {Basin and Range }}$ would not explain the difference between Sierra Nevada and Basin and Range elevations. Instead, a process involving some particular buoyancy source beneath the Sierra Nevada would be required.

The extension must have been "hidden," since there is no significant extensional feature observable at the surface. Little is known about the extension mechanism. Wernicke [1990] proposed as a stretching mechanism, the removal of the midparts of the Sierran quartz-rich crust by laterally pumping it into the 
Table 4. Summary of Relevant Differences Between the Central Sierra Nevada and Eastern Sierra Region Xenolith Suites

\begin{tabular}{ll}
\hline \multicolumn{1}{c}{ Central Sierra Nevada Xenoliths } & Eastern Sierra Region Xenoliths \\
\hline $\begin{array}{l}\text { Age of host } 8-11 \mathrm{Ma} \\
\text { Garnet very common in lower crustal and } \\
\text { upper mantle xenoliths }\end{array}$ & $\begin{array}{c}\text { Age of host } 0-1 \mathrm{Ma} \\
\text { Garnet absent in all xenoliths }\end{array}$ \\
$\begin{array}{l}\text { Deepest crustal rocks, equilibrated at } \sim 2 \\
\text { GPa ( } \sim 65 \mathrm{~km})\end{array}$ & Crustal rocks not found below $\sim 1 \mathrm{GPa}(35 \mathrm{~km})$ \\
Mainly metamorphosed lower crust & \\
(granulite and eclogite facies) & Igneous, nonmetamorphosed lower crustal \\
Adiabatic PT slope below $65 \mathrm{~km} ;$ & xenoliths \\
temperatures $950^{\circ}-1000^{\circ} \mathrm{C}$ & Adiabatic PT slope below 35 km; temperatures \\
Upper mantle most common lithologies: & $1200^{\circ}-1250^{\circ} \mathrm{C}$ \\
lherzolites and garnet websterites & Upper mantle most common lithologies: \\
\hline
\end{tabular}

adjacent Basin and Range. The xenolith data suggest a more likely removal of the mafic lower crust.

We showed that the equilibration pressures of the Central Sierra Nevada suite lower crustal rocks exhibit a distinct change from feldspar-dominated granulites to bimineralic garnet clinopyroxenites at $\sim 1.2 \mathrm{GPa}$. This is consistent with the garnet breakdown reaction (1) that we calculated for the garnet with average xenolith-like composition at the low temperatures of the Cenozoic Sierra Nevada forearc (Figures 5 and 6). The loss of the eclogite facies lowermost crust in the Eastern Sierra and possibly, more recently in the Central Sierra, too, could have taken place by (1) a static process of garnet breakdown as a result of side heating of the Sierra Nevada or (2) a dynamic process.

The first mechanism seems to be negated by the lack of xenoliths in the Eastern Sierra Region carrying the garnet breakdown mineral assemblages. The presence of mantle peridotites as shallow as $35 \mathrm{~km}$ strongly favors the hypothesis of complete lower crustal removal, if an initial, Central-SierraNevada-like, coherent batholithic section throughout the Sierra Nevada is assumed.

A dynamic process involving lower crustal removal is our preferred alternative. Lower crustal mafic rocks are less likely to flow than midcrustal quartz-rich rocks [Wernicke, 1990]. It is possible that the mafic root beneath the Eastern Sierra Region was transported en masse either laterally along a deep, crustalscale detachment surface [Wernicke, 1990], or delaminated and sunk into the less dense peridotitic upper mantle [Kay and Kay, 1993]. There are no data at present to support either mechanism.

The dynamic process of lower crustal removal would lead to the replacement of dense eclogitic assemblages (3400-3550 $\mathrm{kg} / \mathrm{m}^{3}$, based on the average modal composition of the garnet clinopyroxenites of the Central Sierra Nevada, 70\% clinopyroxene and $30 \%$ garnet) with peridotitic upper mantle $(3300$ $\mathrm{kg} / \mathrm{m}^{3}$ ). The $100-250 \mathrm{~kg} / \mathrm{m}^{3}$ decrease in density is a significant buoyancy source. For a $30-\mathrm{km}$ initial thickness of eclogitic lower crust and a $200 \mathrm{~kg} / \mathrm{m}^{3}$ change in density, $1800-\mathrm{m}$ elevation can be supported using the isostatic equilibrium assumption.

Therefore in the Sierra Nevada case, a $\sim 2000-2400 \mathrm{~m}$ subsidence produced by a $\beta$ factor of 2 [White and McKenzie, 1989] would be almost completely annihilated by the density decrease due to eclogite replacement by peridotite. The eclogite removal and peridotite replacement-related buoyancy effect discussed here is the only source we can deduce from the xenolith studies that can significantly enhance buoyancy be- neath the high Sierra Nevada. The process could have removed the central Sierran lower crust since $8 \mathrm{Ma}$ as well.

\section{Conclusions}

We defined two distinct xenolith suites, one from the Central Sierra Nevada (8-10 Ma volcanics) and one from the Eastern Sierra Nevada, Owens Valley, and Inyo Mountains (0-1 Ma volcanics). Thermobarometric data cover the depth range between $\sim 25$ and $100 \mathrm{~km}$ and reveal several differences between the two xenolith suites, which are summarized in Table 4 . The main results from xenolith petrography and thermobarometry are as follows.

1. Central Sierra Nevada lower crustal and mantle xenoliths are commonly garnet bearing, while the Eastern Sierra Nevada xenoliths have no garnet at all.

2. The Central Sierra Nevada lower crustal xenoliths consist of mafic lithologies down to $\sim 65 \mathrm{~km}$. The deeper $25-30 \mathrm{~km}$ of the mafic assemblages were sampled at $\sim 8-10 \mathrm{Ma}$ (host volcanic age) in the eclogite facies as garnet clinopyroxenites. The equilibration of the lowermost mafic crust as eclogite facies rocks is a consequence of the very low heat flows in the Sierra Nevada throughout the Cenozoic [Dumitru, 1990]. It is unclear if there are any more eclogite facies rocks in the Central Sierra Nevada today.

3. The mafic, batholith-related lower crust of the Central Sierra Nevada localities is absent in xenoliths from the Eastern Sierra Nevada region. Mantle peridotites are found in the Eastern Sierra Region below $35 \mathrm{~km}$.

4. The mantle samples deeper than $65 \mathrm{~km}$ in the Central Sierra and $\sim 35 \mathrm{~km}$ in the Eastern Sicrra Region define adiabatic slopes in PT space resembling convective upper mantle behavior. It is very likely that the lithosphere-asthenosphere boundary is very shallow, perhaps close to the base of the crust beneath Owens Valley and the eastern side of the Sierra. The adiabatic-like behavior of the Central Sierra mantle is either a result of small-scale convection in response to crustal thinning or an artifact of heating from the east.

5. There is general agreement between the shallow Moho observed by a recent seismic refraction experiment in the southern Sierra Nevada [Wernicke et al., 1996; S. Ruppert and M. M. Fliedner, submitted manuscript, 1995] and the xenolith thermobarometry, i.e., we systematically recorded lithologies that behave seismically as "mantle" at pressures higher than $1-1.3 \mathrm{GPa}$ (equivalent to $35-45 \mathrm{~km}$ ).

It has been shown that the support mechanism for the Sierra Nevada can be constituted by the replacement of most of the 
lithosphere with asthenosphere if and only if the Sierra Nevada did not experience significant crustal thinning. The amount of thinning experienced by the Sierra Nevada is a parameter of great importance for our understanding of the behavior of rift shoulders, and its determination is currently being addressed. Xenolith evidence from the Eastern Sierra Region suggests a significant thinning of the crust by a factor of 2 or more $(\sim 35$ $\mathrm{km}$ of crust versus $\sim 65-75 \mathrm{~km}$ original crustal thickness). Therefore an additional process must explain the buoyancy of the Sierra Nevada mantle. The replacement of dense, eclogite facies rocks of the preextension Sierra Nevada lowermost crust by peridotitic upper mantle can produce a $\sim 100-250 \mathrm{~kg} / \mathrm{m}^{3}$ decrease in density, enough to annihilate the subsidence effect induced by the thinning itself. The presence of partial melt in the uppermost mantle of the eastern Sierra Nevada has, most likely, a second-order effect in enhancing mantle buoyancy.

Acknowledgments. This research was supported by the Office of Basic Energy Sciences at the Department of Energy (DE-FG0393ER14311). M. Ducea acknowledges a Penrose grant from the Geological Society of America. Extremely valuable journal reviews were provided by Calvin Miller, Ronald Kistler, and an anonymous reviewer. We thank Slawek Tulaczyk, Liz Holt, and Rob Brady for field assistance; Paul Carpenter for electron microprobe logistics help; and Mark Abolins for assistance with Figure 1. The staffs of Sequoia and Kings Canyon National Parks provided critical support for field work. The Southern Sierra Continental Dynamics group is acknowledged for constructive criticism during group meetings. We are particularly thankful to Peter Malin, chief scientist of the project. We thank Sorena Sorensen for providing samples of the Dodge collection, currently stored at the Smithsonian Institution. Earlier versions of this manuscript were improved by Elizabeth Nagy and Slawek Tulaczyk. California Institute of Technology Division of Geological and Planetary Sciences contribution 5550.

\section{References}

Ague, J. J., and G. H. Brimhall, Magmatic arc asymmetry and distribution of anomalous plutonic belts in the batholiths of California: Effects of assimilation, crustal thickness and depth of crystallization, Geol. Soc. Am. Bull., 100, 912-927, 1988.

Atwater, T., and P. H. Molnar, Relative motion of the Pacific and North American plates deduced from sea spreading in the Atlantic, Indian, and South Pacific Oceans, Proceedings of the Conference on Tectonic problems of the San Andreas fault System, Stanford, California, Stanford Univ. Publ. Geol. Sci., 13, 136-148, 1973.

Basaltic Volcanism Study Project, Basaltc Volcanism in the Terrestrial Planets, Pergamon, New York, 1981.

Bateman, P. C., and J. P. Eaton, The Sierra Nevada batholith, Science, 158, 1407-1417, 1967.

Beard, B. L., and A. F. Glazner, Trace element and $\mathrm{Sr}$ and Nd isotopic composition of mantle xenoliths from the Big Pine Volcanic Field, California, J. Geophys. Res., 100(B3), 4169-4179, 1995.

Brey, G. P., and T. Kohler, Geothermobarometry in four-phase lherzolites, II, New thermobarometers and practical assessment of existing thermobarometers, J. Petrol., 31, 1353-1378, 1990.

Brey, G. P., K. G. Nickel, and L. Kogarko, Garnet-pyroxene equilibria in the system $\mathrm{CaO}-\mathrm{MgO}-\mathrm{Al}_{2} \mathrm{O}_{3}-\mathrm{SiO}_{2}$ : Prospects for simplified (T-independent) lherzolite barometry and an eclogite barometer, Contrib. Mineral. Petrol., 92, 448-455, 1986.

Buck, W. R., Small-scale convection induced by passive rifting: The case for uplift of rift shoulders, Earth Planet. Sci. Lett., 77, 362-372, 1985.

Clemens-Knott, D., Geologic and isotopic investigations of the early Cretaceous Sierra Nevada batholith, Tulare, CA, and the Ivrea zone, NW Italian Alps: Example of interaction between mantle-derived magma and continental crust, Ph.D. thesis, 345 pp., Calif. Inst. of Technol., Pasadena, 1992.

Cochran, J. R., The magnetic quiet zone in the eastern Gulf of Aden: Implications for the early development of the continental margin, Geophys. J. R. Astron. Soc., 68, 171-201, 1982.
Coleman, R. G., D. E. Lee, J. B. Beatty, and W. W. Brannock, Eclogites and eclogites: Their differences and similarities, Geol. Soc. Am. Bull., 76, 483-508, 1965.

Crough, S. T., and G. A. Thompson, Upper mantle origin of the Sierra Nevada uplift, Geology, 5, 396-399, 1977.

Dewey, J. F., P. D. Ryan, and T. B. Andersen, Orogenic uplift and collapse, crustal thickness, fabrics and metamorphic phase changes: The role of eclogites, in Magmatic Processes and Plate Tectonics, edited by H. M. Prichard et al., Spec. Publ. Geol. Soc. Am., 76, 325-343, 1993.

Dodge, F. C. W., and P. C. Bateman, Nature and origin of the root of the Sierra Nevada, Am. J. Sci., 288A, 341-357, 1988.

Dodge, F. C. W., L. C. Calk, and R. W. Kistler, Lower crustal xenoliths, Chinese Peak lava flow, Central Sierra Nevada, J. Petrol., 27, 1277-1304, 1986.

Dodge, F. C. W., J. P. Lockwood, and L. C. Calk, Fragments of the mantle and crust beneath the Sierra Nevada batholith: Xenoliths in a volcanic pipe near Big Creek, California, Geol. Soc. Am. Bull., 100, 938-947, 1988

Domenick, M. A., R. W. Kistler, F. C. W. Dodge, and M. Tatsumoto, $\mathrm{Nd}$ and $\mathrm{S}_{\mathrm{r}}$ isotopic study of crustal and mantle inclusions from the Sierra Nevada and implications for batholith petrogenesis, Geol. Soc. Am. Bull., 94, 713-719, 1983.

Ducea, M. N., and J. B. Saleeby, Thermobarometric constraints on the deep crustal-upper mantle composition of the Sierra Nevada, California, from mafic and ultramafic xenoliths, (abstract), Eos Trans. $A G U, 75$, Fall Meet. Suppl., 583, 1994.

Ducea, M. N., R. W. Kistler, and J. B. Saleeby, Testing petrogenetic models for the Sierra Nevada lithosphere with REE data on crustal and mantle xenoliths, Geol. Soc. Am. Abstr. Programs, 27, 15-16, 1995.

Dumitru, T. A., Subnormal Cenozoic geothermal gradients in the extinct Sierra Nevada magmatic arc: Consequences of Laramide and post-Laramide shallow angle subduction, J. Geophys. Res., 95(B4), 4925-4941, 1990.

Ellis, D. J., and E. H. Green, An experimental study of the effect of Ca upon garnet-clinopyroxene $\mathrm{Fe}-\mathrm{Mg}$ exchange equilibria, Contrib. Mineral. Petrol., 66, 13-22, 1979.

Frost, R. B., and T. Chacko, The granulite uncertainty principle: Limitations on thermobarometry in granulites, J. Geol., 97, 435-450, 1989.

Griffin, W. L., and S. Y. O'Reilly, The lower crust in eastern Australia: Xenolith evidence, in The Nature of the Lower Continental Crust, edited by J. B. Dawson, et al., Spec. Publ. Geol. Soc. Am., 24, 363-374, 1986.

Hanchar, J. M., C. F. Miller, J. L. Wooden, V. C. Bennett, and J. M. Staude, Evidence from xenoliths for a dynamic lower crust: Eastern Mojave Desert, California, J. Petrol., 35, 1377-1415, 1994.

Harley, S. L., An experimental study of the partitioning of Fe and $\mathrm{Mg}$ between garnet and orthopyroxene, Contrib. Mineral. Petrol., 86, 359-373, 1984.

Harley, S. L., and D. H. Green, Garnet-orthopyroxene barometry for granulites and peridotites, Nature, 300, 697-701, 1982.

Henyey, T. L., and T. C. Lee, Heat flow in the Lake Tahoe, CaliforniaNevada, and the Sierra Nevada-Basin and Range transition, Geol. Soc. Am. Bull., 87, 1179-1187, 1976.

Isacks, B. L., Uplift of the central Andrean Plateau and bending of the Bolivian orocline, J. Geophys. Res., 93(B4), 3211-3231, 1988.

Ito, K., and G. C. Kennedy, The fine structure of the basalt-eclogite transition, Mineral. Soc. Am. Spec. Pap., 2, 179-191, 1970.

Jones, C. H., Is extension in Death Valley accommodated by thinning of the mantle lithosphere beneath the Sierra Nevada, California?, Tectonics, 6, 449-473, 1987.

Jones, C. H., H. Kanamori, and S. W. Roecker, Missing roots and mantle "drips": Regional $\boldsymbol{P}_{\boldsymbol{n}}$ and teleseismic arrival times in the southern Sierra Nevada and vicinity, California, J. Geophys. Res., 99, 4567-4601, 1994.

Kay, R. W., and S. M. Kay, Petrology and geochemistry of the lower continental crust: An overview, in The Nature of the Lower Continental Crust, edited by J. B. Dawson, et al., Spec. Publ. Geol. Soc. Am., 24, 147-159, 1986.

Kay, R. W., and S. M. Kay, Delamination and delamination magmatism, Tectonophysics, 219, 177-189, 1993.

Kohler, T., and G. P. Brey, Calcium exchange between olivine and clinopyroxene calibrated as a geothermobarometer for natural peri- 
dotites from 2 to $60 \mathrm{kbar}$ with applications, Geochim. Cosmochim. Acta, 54, 2375-2388, 1990.

Lachenbruch, A. H., and J. H. Sass, Heat flow in the United States and the thermal regime of the crust, in The Earth's Crust, Its Nature and Physical Properties, Geophys. Monogr. Ser., vol. 20, edited by J. G. Heacock, pp. 626-675, AGU, Washington, D. C., 1977.

Luedke, R. G., and R. L. Smith, Map showing distribution, composition, and age of late Cenozoic volcanic centers in California and Nevada, U.S. Geol. Sun. Misc. Invest. Ser. Map, I091-C, 1981.

Mansfield, C. F., Upper Mesozoic subsea fan deposits in the southern Diablo Range, California, record of the Sierra Nevada magmatic arc, Geol. Soc. Am. Bull., 90, 1025-1046, 1979.

McKenzie, D., Some remarks on the development of the sedimentary basins, Earth Planet. Sci. Lett., 40, 25-32, 1978.

McKenzie, D., and M. J. Bickle, The volume and composition of melt generated by extension of the lithosphere, J. Petrol., 29, 625-679, 1988.

Meissner, R., The Continental Crust: A Geophysical Approach, Academic, San Diego, Calif., 1986.

Mooney, W. D., and C. S. Weaver, Regional crustal structure and tectonics of the Pacific Coastal States: California, Oregon and Washington, in Geophysical Framework of the Continental United States, edited by L. C. Pakiser and W. D. Mooney, Mem. Geol. Soc. Am., 172, 129-159, 1989.

Moore, J. C., and T. W. Sisson, Geologic map of the Kern Peak Quadrangle, Tulare County, California, U.S. Geol. Surv. Geol. Quadrangle Map Ser., GQ-1584, 1985.

Mukhopadhyay, B., Petrology and geochemistry of mafic and ultramafic xenoliths from the Sierra Nevada batholith, Part 1, Ph.D. dissertation, 215 pp., Univ. of Texas at Dallas, 1989.

Mukhopadhyay, B., Garnet-clinopyroxene barometry: The problems, a prospect and approximate solution with some applications, $\mathrm{Am}$. Mineral., 76, 512-529, 1991a.

Mukhopadhyay, B., Garnet breakdown in some deep seated garnetiferous xenoliths from the central Sierra Nevada: Petrologic and tectonic implications, Lithos, 27, 59-78, 1991b.

Mukhopadhyay, B., and W. I. Manton, Upper mantle fragments from beneath the Sierra Nevada batholith- partial fusion, fractional crystallization and metasomatism in a subduction-related ancient lithosphere, J. Petrol., 35, 1418-1450, 1994.

Newton, R. C., and D. Perkins, Thermodynamic calibration of geobarometers based on the assemblages garnet-plagioclase-orthopyroxene(clinopyroxene)-quartz, Am. Mineral., 67, 203-222, 1982.

Oliver, H. W., Gravity and magnetic investigations of the Sierra Nevada batholith, California, Geol. Soc. Am. Bull., 88, 445-461, 1977.

Ormerod, D. S., C. J. Hawkesworth, N. K. Rogers, W. P. Leeman, and M. A. Menzies, Tectonic and magmatic transitions in the Western Great Basin, USA, Nature, 333, 349-353, 1988.

Papike, J. J., K. L. Cameroon, and K. Baldwin, Amphiboles and pyroxenes; Characterization of other than quadrilateral components and estimates of ferric iron from microprobe data, Geol. Soc. Am. Abstr. Programs, 6, 1053-1054, 1974.

Park, S., R. Clayton, M. Ducea, C. Jones, B. Wernicke, and S. Ruppert, Project combines seismic and magnetotelluric surveying to address the Sierran root question, Eos Trans. AGU, 76, 297-298, 1995.

Perkins, D., III, and S. J. Chipera, Garnet-orthopyroxene-plagioclasequartz barometry: Refinement and application to the English River subprovince and the Minnesota River valley, Contrib. Mineral. Petrol., 89, 69-80, 1985.

Perkins, D., III, and R. C. Newton, Charnockite geobarometers based on coexisting garnet-plagioclase-pyroxenc-quartz, Nature, 292, 144 $146,1981$.

Pickett, D. A., and J. B. Saleeby, Thermoharometric constraints on the depth of exposure and conditions of plutonism and metamorphism at deep levels of the Sierra Nevada batholith, Tehachapi Mountains, California, J. Geophys. Res., 98(B1), 609-629, 1993.

Powell, R., and T. J. B. Holland, An internally consistent thermodynamic dataset with uncertainties and correlations, 3 , Applications to geobarometry, worked examples and a computer program, J. Metamorphic Petrol., 6, 173-204, 1988.

Renne, P. R., O. T. Tobish, and J. B. Saleeby, Thermochronologic record of pluton emplacement, deformation and exhumation at Courtright shear zone, central Sierra Nevada, California, Geology, 21, 331-334, 1993.

Rudnick, R. L., Xenoliths: Samples of the lower continental crust, in Lower Continental Crust, Dev. in Geotectonics, vol. 23, edited by D. M. Fountain, R. Arculus, and R. W. Kay, pp. 269-317, Elsevier, New York, 1992.

Rudnick, R. L., and S. R. Taylor, The composition and petrogenesis of the lower crust: A xenolith study, J. Geophys. Res., 92(B13), 13,981$14,005,1987$.

Sack, R. O., and M. S. Ghiorso, Chromian spinels as petrogenetic indicators: Thermodynamics and petrological applications, $\mathrm{Am}$. Mineral., 76, 827-847, 1991.

Saleeby, J. B., Progress in tectonic and petrogenetic studies in an exposed cross-section of young (c. $100 \mathrm{Ma}$ ) continental crust, southern Sierra Nevada, California, in Exposed Crustal Sections of the Continental Crust, edited by M. H. Salisbury and D. M. Fountain, pp. 137-158, Kluwer Acad., Norwell, Mass., 1990.

Saleeby, J. B., and W. D. Sharp, Chronology of the structural and petrologic development of the southwest Sierra Nevada foothills, California: Summary, Geol. Soc. Am. Bull., Part 1, 91, 317-320, 1982.

Taylor, S. R., and S. M. McLennan, The Continental Crust: Its Compositional Evolution, 312 pp., Blackwell Sci., Cambridge, Mass., 1985.

Wells, P. R. A., Pyroxene thermometry in simple and complex systems, Contrib. Mineral. Petrol., 62, 129-139, 1977.

Wernicke, B., The fluid crustal layer and its implications for continental dynamics, in Exposed Cross Sections of the Continental Crust, NATO Adv. Study Ser., Ser. C, Math. and Phys. Sci., vol. 317, edited by M. H. Salisbury and D. M. Fountain, pp. 509-544, Kluwer Acad., Norwell, Mass., 1990.

Wernicke, B., Cenozoic extensional tectonics of the western U.S. Cordillera, in The Cordilleran Orogen, Conterminous United States, Geol. of North Am., vol. G-3, edited by B. C. Burchfiel, pp. 111-116, Geol. Soc. of Am., Boulder, Colo., 1992.

Wernicke, B., et al., Origins of high mountains on continents: The Southern Sierra Nevada, Science, 271, 190-193, 1996.

White, R., and D. McKenzie, Magmatism at rift zones: The generation of volcanic continental margins and flood basalts, J. Geophys. Res., 94(B6), 7685-7729, 1989.

Wilshire, H. G., C. E. Meyer, J. K. Nakata, L. C. Calk, J. W. Shervais, J. E. Nielson, and E. C. Schwarzman, Mafic and ultramafic xenoliths from volcanic rocks of the western United States, U.S. Geol. Surv. Prof. Pap., 1443, 179 pp., 1988.

Wyllie, P. J., The nature of the Mohorovicic discontinuity: A compromise, J. Geophys. Res., 68, 4611-4619, 1963.

Zhang, Q., M. Enami, and K. Suawa, Aluminian orthopyroxene in a pyrometamorphosed garnet megacryst from Liaoning and Shandong provinces, northeast China, Eur. J. Mineral., 5, 153-164, 1993.

M. N. Ducea and J. B. Saleeby, Division of Geological and Planetary Sciences, California Institute of Technology, Pasadena, CA 91125. (e-mail: ducea@legs.gps.caltech.edu)

(Received June 20, 1995; revised November 2, 1995; accepted November 9, 1995.) 